\title{
Hydrology and Geochemistry of Thermal Ground Water in Southwestern Idaho and North-Central Nevada
}

By H. W. YOUNG and R. E. LEWIS

GEOHYDROLOGY OF GEOTHERMAL SYSTEMS

GEOLOGICAL SURVEY PROFESIONAL PAPER $1044-\mathrm{J}$

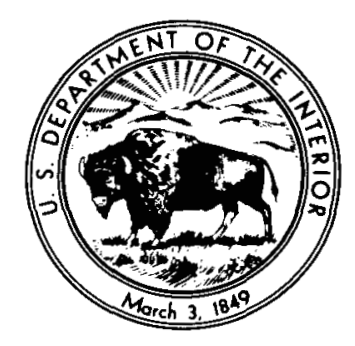




\section{UNITED STATES DEPARTMENT OF THE INTERIOR}

JAMES G. WATT, Secretary

\section{GEOLOGICAL SURVEY}

Dallas L. Peck, Director

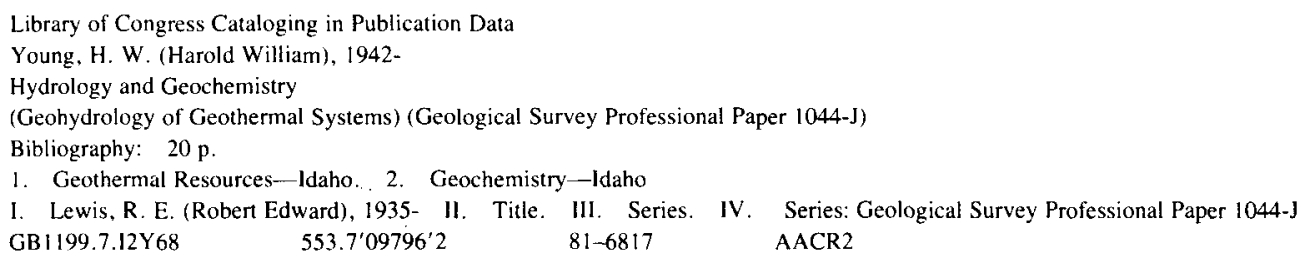

For sale by the Branch of Distribution, U.S. Geological Survey, 604 South Pickett Street, Alexandria, VA 22304 


\section{DISCLAIMER}

This report was prepared as an account of work sponsored by an agency of the United States Government. Neither the United States Government nor any agency Thereof, nor any of their employees, makes any warranty, express or implied, or assumes any legal liability or responsibility for the accuracy, completeness, or usefulness of any information, apparatus, product, or process disclosed, or represents that its use would not infringe privately owned rights. Reference herein to any specific commercial product, process, or service by trade name, trademark, manufacturer, or otherwise does not necessarily constitute or imply its endorsement, recommendation, or favoring by the United States Government or any agency thereof. The views and opinions of authors expressed herein do not necessarily state or reflect those of the United States Government or any agency thereof. 


\section{DISCLAIMER}

Portions of this document may be illegible in electronic image products. Images are produced from the best available original document. 


\section{CONTENTS}

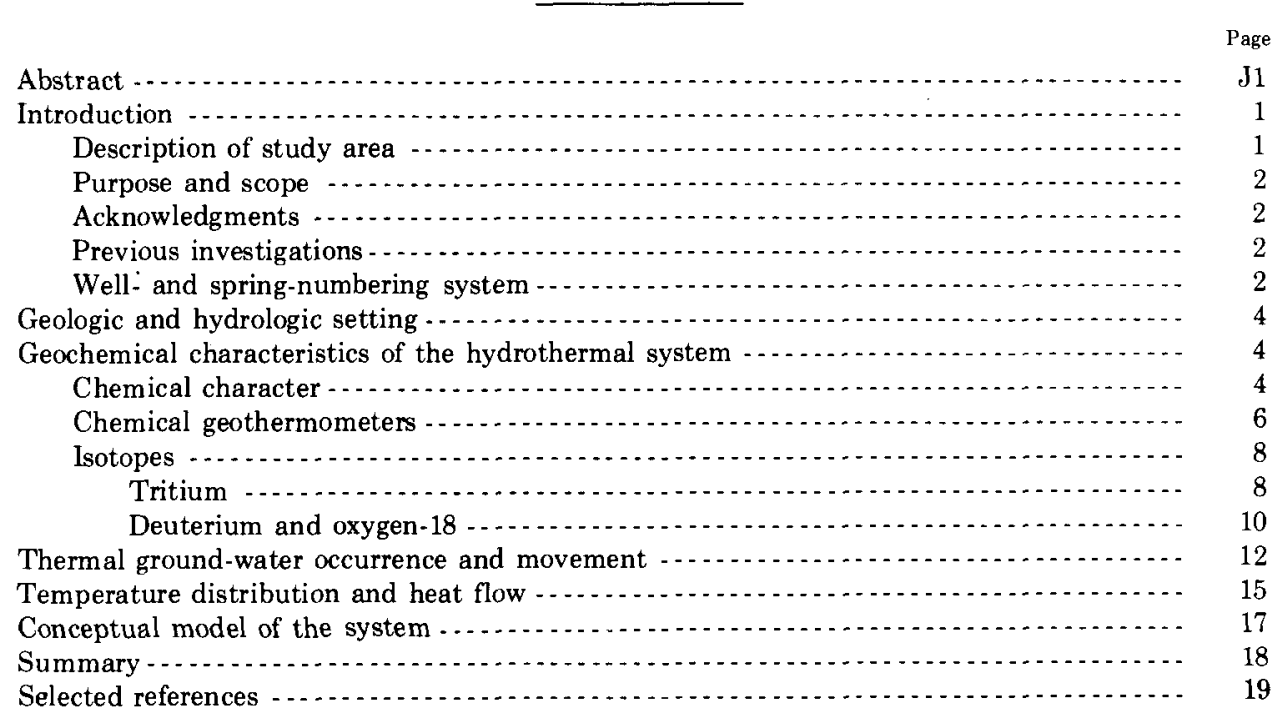

\section{ILLUSTRATIONS}

Plate 1. Map showing generalized geology of southwestern Idaho and north-central

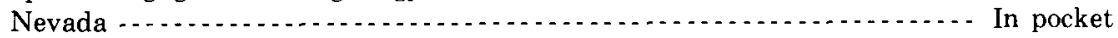

2. Map showing generalized potentiometric surface of thermal water and hydrologic-data site locations in southwestem Idaho and north-central Nevada -. In pocket

Figures 1-4. Diagrams showing:

1. Well- and spring-numbering system $\ldots \ldots \ldots$ J3

2. Comparison of reservoir temperatures estimated by the silica and sodium-potassium-calcium geothermometers - .....................

3. Tritium content of water assuming piston-flow and well-mixed groundwater systems in Yellowstone National Park ....................

4. Relations between concentrations of deuterium and oxygen-18 .......

\section{TABLES}

TABLE 1. Chemical analyses of water from selected wells and springs
2. Estimated reservoir temperatures and free energy of formation for selected hot-

water wells and hot springs

3. Tritium in water from selected wells and springs

4. Stable-isotope analyses of water from selected wells and springs

6. Estimated thermal-water discharge, on the basis of enthalpy $\ldots \ldots$ 


\section{CONVERSION FACTORS}

The following conversion table is included for the convenience of those who prefer to use the SI (International System of Units) rather than the inch-pound system of units. Chemical data for concentrations are given in $\mathrm{mg} / \mathrm{L}$ (milligrams per liter) or $\mu \mathrm{g} / \mathrm{L}$ (micrograms per liter), which are, within the range of values presented, numerically equal to parts per million or parts per billion, respectively. Thermal parameters are reported in "working" units.

\begin{tabular}{|c|c|c|}
\hline Multiply inch-pound unit & By & To obtain SI unit \\
\hline \multicolumn{3}{|c|}{ Length } \\
\hline $\begin{array}{l}\operatorname{inch}(\mathrm{in} .) \\
\text { foot (ft) } \\
\text { mile (mi) }\end{array}$ & $\begin{array}{l}25.40 \\
0.3048 \\
1.609\end{array}$ & $\begin{array}{l}\text { millimeter } \\
\text { meter } \\
\text { kilometer }\end{array}$ \\
\hline \multicolumn{3}{|c|}{ Area } \\
\hline $\begin{array}{l}\text { acre } \\
\text { square mile }\left(\mathrm{mi}^{2}\right)\end{array}$ & $\begin{array}{l}4047 \\
\quad 2.590\end{array}$ & $\begin{array}{l}\text { square meter } \\
\text { square kilometer }\end{array}$ \\
\hline \multicolumn{3}{|c|}{ Volume } \\
\hline $\begin{array}{l}\text { acre-foot }(\text { acre- } \mathrm{ft}) \\
\text { cubic foot }\left(\mathrm{ft}^{3}\right) \\
\text { cubic mile }\left(\mathrm{mi}^{3}\right)\end{array}$ & $\begin{array}{l}1233 \\
\quad 0.02832 \\
4.168\end{array}$ & $\begin{array}{l}\text { cubic meter } \\
\text { cubic meter } \\
\text { cubic kilometer }\end{array}$ \\
\hline \multicolumn{3}{|c|}{ Volume Per Unit Time } \\
\hline $\begin{array}{l}\text { gallon per minute }(\mathrm{gal} / \mathrm{min}) \\
\text { cubic foot per second }\left(\mathrm{ft}^{3} / \mathrm{s}\right)\end{array}$ & $\begin{array}{r}0.06309 \\
.02832\end{array}$ & $\begin{array}{l}\text { liter per second } \\
\text { cubic meter per second }\end{array}$ \\
\hline Multiply working unit & By & To obtain SI unit \\
\hline \multicolumn{3}{|c|}{ Energy and Power } \\
\hline $\begin{array}{l}\text { calorie (cal) } \\
\text { calorie per second (cal/s) }\end{array}$ & $\begin{array}{l}4.187 \\
4.187\end{array}$ & $\begin{array}{l}\text { joule } \\
\text { joule per second; watt }\end{array}$ \\
\hline \multicolumn{3}{|c|}{ Heat Flux Density } \\
\hline $\begin{array}{l}\text { microcalorie per square } \\
\text { centimeter } \cdot \text { second } \\
\left(\mu \mathrm{cal} / \mathrm{cm}^{2} \cdot \mathrm{s}\right) \text { heat flow } \\
\text { unit }(\mathrm{HFU})\end{array}$ & $4.187 \times 10^{-2}$ & watt per square meter \\
\hline \multicolumn{3}{|c|}{ Thermal Conductivity } \\
\hline $\begin{array}{l}\text { calorie per centimeter } \\
\text { second } \cdot \operatorname{deg} r e e \text { Celsius } \\
\mathrm{cal} /\left(\mathrm{cm} \cdot \mathrm{s} \cdot{ }^{\circ} \mathrm{C}\right)\end{array}$ & $4.187 \times 10^{2}$ & $\begin{array}{l}\text { watt per meter } \cdot \text { degree } \\
\text { kelvin }\end{array}$ \\
\hline & Temperature & \\
\hline
\end{tabular}

Conversion of ${ }^{\circ} \mathrm{C}$ (degrees Celsius) to ${ }^{\circ} \mathrm{F}$ (degrees Fahrenheit) is based on the equation ${ }^{\circ} \mathrm{F}=(1.8)\left({ }^{\circ} \mathrm{C}\right)+32$. Water temperatures are reported to the nearest one-half degree. 


\title{
HYDROLOGY AND GEOCHEMISTRY OF THERMAL GROUND WATER IN SOUTHWESTERN IDAHO AND NORTH-CENTRAL NEVADA
}

\author{
By H. W. YOUNG and R. E. LEWIS
}

\begin{abstract}
The study area occupies about 14,500 square miles in southwestern Idaho and north-central Nevada. Thermal ground water occurs under artesian conditions, in discontinuous or compartmented zones, in igneous or sedimentary rocks of Tertiary age. Ground-water movement is generally northward. Temperatures of the ground water range from about $30^{\circ}$ to more than $80^{\circ}$ Celsius.

Chemical analyses of water from 12 wells and 9 springs indicate that nonthermal waters are a calcium bicarbonate type; thermal waters are a sodium carbonate or bicarbonate type. Chemical geothermometers indicate probable maximum reservoir temperatures are near $100^{\circ}$ Celsius. Concentration of tritium in the thermal water is near zero,

Depletion of stable isptopes in the hot waters relative to present-day meteoric waters indicates recharge to the system probably occurred when the climate averaged $3^{\circ}$ to $5^{\circ}$ Celsius colder than at present. Temperatures about $3.5^{\circ}$ Celsius colder than at present occurred during periods of recorded Holocene glacial advances and indicate a residence time of water in the system of at least several thousand years. Residence time calculated on the basis of reservoir volume and thermal-water discharge is 3,400 to 6,800 years for an effective reservoir porosity of 0.05 and 0.10 , respectively. Preliminary analyses of carbon-14 determinations indicate an age of the hot waters of about $18,000-25,000$ years.

Water is heated to temperatures between $80^{\circ}$ and $100^{\circ}$ Celsius by circulation in the Idavada Volcanics to depths of about 5,000 feet. Water of about $80^{\circ}$ Celsius occurs in wells about 2,900 feet, which suggests transfer of heat convectively within the Idavada Volcanics. Heat flux into the system is about $8.7 \times 10^{7}$ calories per second. With about $4.3 \times 10^{7}$ and $1.6 \times 10^{7}$ calories per second discharged by conduction and thermal springs, respectively, 25.0 cubic feet per second, or about 18,000 acre-feet per year of $50^{\circ}$ Celsius water is required to transport $2.8 \times 10^{7}$ calories per second advectively in ground water moving northward out of the area.

The proposed conceptual model for the area is one of an old system, where water has circulated for thousands, even tens of thousands, of years. Within constraints imposed by the model described, reservoir thermal energy for the geothermal system in southwestern Idaho and north-central Nevada is about $130 \times 10^{18}$ calories.
\end{abstract}

\section{INTRODUCTION}

Thermal ground water occurs over a large area south of the Snake River in Owyhee and Twin Falls Counties in southwestern Idaho and northern Elko County in northcentral Nevada (pl. 1). The area supports a rural population dependent primarily on irrigated agriculture and ranching. Wells drilled for irrigation generally yield thermal water, which ranges in temperature from $15^{\circ}$ to more than $80^{\circ} \mathrm{C}$. For use in this report, thermal waters that have temperatures between $40^{\circ}$ and $81^{\circ} \mathrm{C}$ are referred to as hot waters; waters that have temperatures between $20^{\circ}$ and $30^{\circ} \mathrm{C}$ are referred to as warm waters. Cold, nonthermal water in the area is generally $12^{\circ} \mathrm{C}$ or less.

Except for some space heating of homes locally, development of the thermal ground-water resource in the area has been largely for irrigation; consequently, thermal energy associated with the resource is unused. Although temperatures of the thermal water are only moderate, because of the very large reservoir volume, the available thermal energy in the geothermal system is enormous. The most recent assessment of the geothermal resources of the United States (Brook and others, 1979 ) indicates that the geothermal energy contained in the hydrothermal systems in this area is the largest outside of Yellowstone National Park and represents almost one-third of the energy in known systems above $90^{\circ} \mathrm{C}$.

This study is an effort to further evaluate this large resource and is part of a comprehensive program by the U.S. Geological Survey to better understand the nature and occurrence of the geothermal resources in the Nation.

\section{DESCRIPTION OF STUDY AREA}

The study area includes about $14,500 \mathrm{mi}^{2}$ in Owyhee and western Twin Falls Counties in southwestern Idaho, from the Oregon border eastward to Twin Falls, and northern Elko County in north-central Nevada (pl. 1). Included in this study is the $1,100 \mathrm{mi}^{2}$ Bruneau-Grand View area described by Young and Whitehead (1975) in northern Owyhee County. (See pl. 1 for boundaries of Bruneau-Grand View area.) Later references are made to a "Bruneau-Grand View area" by White and Williams (1975), who stated that areal boundaries include $869 \mathrm{mi}^{2}$ on the basis of "surface manifestations, geophysical data, well records, and geologic inference." Brook and others $(1979$, p. 34) stated that the Bruneau-Grand View area consists of $573 \mathrm{mi}^{2}$ on the basis of "twice the identified component." The Bruneau and most of the Castle Creek KGRA's (known geothermal resource areas) are within the study area.

Climate in the region is semiarid, characterized by 
hot, dry summers and cool winters. Topography is varied. The Jarbidge and Owyhee Mountains rise to altitudes of 10,185 and 8,122 ft, respectively. Much of the area consists of extensive plateaus, which range in altitude from 3,000 to $7,000 \mathrm{ft}$. Lowlands include the Snake River valley, where altitudes range from 2,000 to $3,800 \mathrm{ft}$.

Perennial and intermittent streams drain the area. Principal drainages include the Bruneau and Owyhee Rivers and Salmon Falls Creek. These streams head in the Owyhee and Jarbidge Mountains and flow north across the plateaus in deeply incised canyons to the Snake River.

\section{PURPOSE AND SCOPE}

The purposes of this report are to describe the hydrology and geochemistry, to better define the areal limits of thermal water in southwestern Idaho and northcentral Nevada, and to develop a conceptual model of the system that contains the thermal water.

Water samples from 12 wells and 9 springs were collected for chemical analyses. Constituents analyzed include the common ions and silica, and the minor elements arsenic, boron, lithium, and mercury. Additional samples for isotope analyses were collected from wells and springs that were representative of thermal and nonthermal waters in the area. Six wells and six springs were sampled for tritium and four wells and nine springs for deuterium and oxygen-18. In addition, water levels were measured or reported values were obtained for 148 wells, and a generalized potentiometric-surface map was constructed. Where possible, water temperatures were measured or reported values were obtained. For all thermal-water wells and springs sampled, reservoir temperatures were estimated using the silica and $\mathrm{Na}-\mathrm{K}$ $\mathrm{Ca}$ (sodium-potassium-calcium) geothermometers. Ratios of selected chemical constituents, concentrations of deuterium and oxygen-18, and tritium in sampled waters were used to characterize and thereby distinguish water from different aquifers.

\section{ACKNOWLEDGMENTS}

Many farmers and landowners in Owyhee and Twin Falls Counties in southwestern Idaho and Elko County in north-central Nevada cooperated fully in this study. The authors express appreciation to these residents for allowing water-level measurements and water-quality samples to be obtained from their wells and for allowing access to their property. Several colleagues within the Geological Survey contributed significantly to this investigation: A. H. Truesdell and N. L. Nehring provided sulfate-isotope analyses; discussions with R. H. Mariner aided in interpretation of geochemical data; $T$. A.
Wyerman performed tritium-isotope analyses; and $\mathrm{M}$. Nathenson assisted with calculations for converting hotwater heads to their cold-water equivalents.

\section{PREVIOUS INVESTIGATIONS}

Data from known hot springs in southwestern Idaho and north-central Nevada are included in Stearns, Stearns, and Waring (1937). Historical data from thermal springs and wells in southwestern Idaho were summarized by Ross (1971); however, few water-chemistry data were presented. Young and Mitchell (1973) gave chemical analyses from 16 hot-water wells and 6 hot springs in Owyhee and Twin Falls Counties in their evaluation of thermal water in Idaho. They recommended that additional studies be made in 23 areas of the State where aquifer temperatures greater than $140^{\circ} \mathrm{C}$ were indicated. On those recommendations, Young and Whitehead (1975) inventoried and sampled 94 wells and springs in the Bruneau-Grand View area. In addition to compilation of chemical data, their report contains (1) a description of the areal extent and chemical character of the thermal water, (2) estimates of reservoir temperatures using chemical geothermometers, (3) a description of geophysical data available for the area, (4) a description of geology, and (5) a description of the probable source of the thermal water. Rightmire, Young, and Whitehead (1976) collected and analyzed isotopic and geochemical data for the Bruneau-Grand View area to determine the possible source of recharge to the hydrothermal system. On the basis of an estimated subsurface temperature of $145^{\circ} \mathrm{C}$ and reservoir volume of $810 \mathrm{mi}^{3}$, Renner, White, and Williams (1975, p. 38-39) calculated that heat stored in the Bruneau-Grand View geothermal system was about $263 \times 10^{18}$ cal. A more recent estimate by Brook and others (1979, table 6) places the stored heat at $107 \pm 26 \times 10^{18} \mathrm{cal}$, on the basis of a mean reservoir temperature of $107 \pm 6^{\circ} \mathrm{C}$ and reservoir volume of $439 \pm 101 \mathrm{mi}^{3}$. Young, Lewis, and Backsen (1979) estimated the discharge of thermal ground water and associated convective heat flux from wells and springs in the Bruneau-Grand View area in 1978 to be $50,500 \mathrm{acre}-\mathrm{ft} / \mathrm{yr}$ and $4.97 \times 10^{7} \mathrm{cal} / \mathrm{s}$, respectively.

\section{WELL- AND SPRING-NUMBERING SYSTEM}

The well- and spring-numbering system (fig. 1) used by the U.S. Geological Survey in Idaho indicates the location of wells or springs within the official rectangular subdivision of the public lands, with reference to the Boise base line and meridian. The first two segments of the number designate the township and range. The third segment gives the section number, followed by three let- 


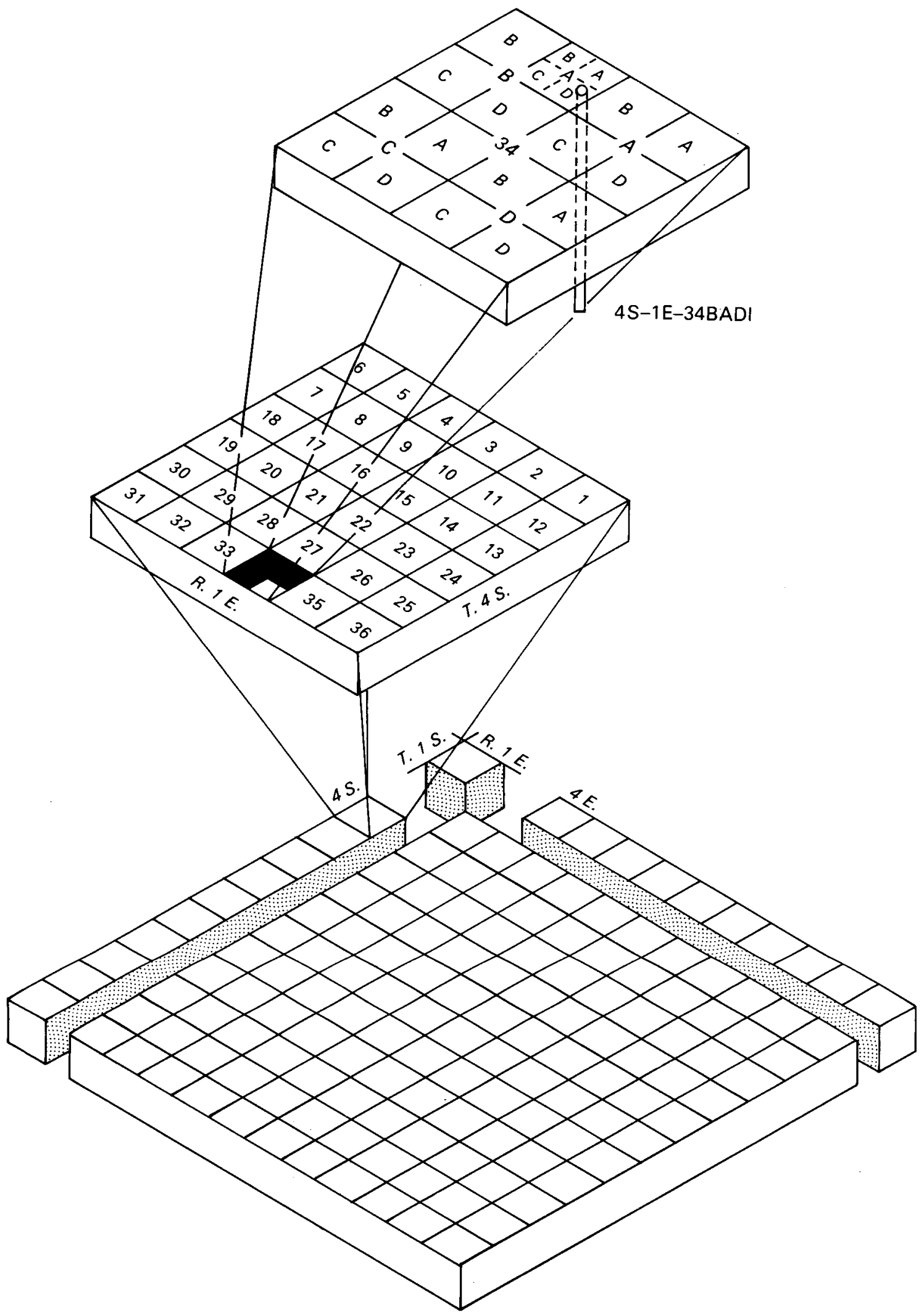

F IGURE 1.-Well- and spring-numbering system. 
ters and a numeral, which indicate the $1 / 4$ section $(160$ acre tract), the $1 / 4-1 / 4$ section ( 40 -acre tract), the $1 / 4-1 / 4-1 / 4$ section (10-acre tract), and the serial number of the well within the tract, respectively. Quarter sections are lettered A, B, C, and D in counterclockwise order from the northeast quarter of each section. Within the quarter sections, 40-acre and 10-acre tracts are lettered in the same manner. Well $4 \mathrm{~S}-1 \mathrm{E}-34 \mathrm{BAD} 1$ is in the $\mathrm{SE}^{1 / 4} \mathrm{NE}^{1 / 4} \mathrm{NW}^{1 / 4}$ sec. 34, T. 4 S., R. 1 E., and is the first well inventoried in that tract. Springs are designated by the letter "S" following the last numeral; for example, $14 \mathrm{~S}-14 \mathrm{E}-11 \mathrm{CAB} 1 \mathrm{~S}$. Wells and springs in Nevada are located in the same manner with reference to the Mount Diablo base line and meridian.

\section{GEOLOGIC AND HYDROLOGIC SETTING}

The rocks of southwestern Idaho and north-central Nevada range in age from Precambrian to Holocene and represent a varied and complex geologic history. Tertiary lava flows ranging in composition from rhyolite to basalt form much of the uplands and plateaus. Tertiary and Quaternary sedimentary rocks cover most of the lower areas and are locally overlain by Quarternary basalt. The cores of the Owyhee and Jarbidge Mountains are composed of sedimentary and metamorphic rocks of Precambrian and Paleozoic age, intruded by granitic rocks of Mesozoic and Tertiary age.

For purposes of this report, the geology of the area is generalized and divided into six units. (See pl. 1 for areal extent and description.) Each unit is delineated on the gasis of age, origin, and lithology. Three of the geologic units are related to occurrence of thermal ground water: sedimentary rocks of Quaternary and Tertiary age, basalt of Quaternary and Tertiary age, and silicic volcanic rocks of Tertiary age.

The sedimentary unit, consisting chiefly of rocks of the Idaho Group, contains thermal ground water in the northern part of the study area. This sequence of fluvial and lacustrine deposits, ranging from clay to gravel, has a maximum thickness of about 2,000 ft near Oreana and Grand View, Idaho (Young and Whitehead, 1975).

The basalt unit, which consists chiefly of Banbury Basalt, is exposed throughout the study area. This unit is also widespread in the subsurface and, along with rocks of the Idavada Volcanics, contains most of the thermal ground water. The thickness of the basalt unit varies and is unknown in many parts of the area. In the Bruneau-Grand View area, Young and Whitehead (1975) indicated that the unit ranges in thickness from less than $100 \mathrm{ft}$ to nearly $1,200 \mathrm{ft}$.

The silicic volcanic rock unit, which includes the Idavada Volcanics, is also exposed throughout the area south of the Snake River Plain and may underlie the entire study area. Thickness of the Idavada Volcanics is probably 2,000-3,000 ft; however, the total thickness of the silicic volcanic rock unit is largely unknown and may be as much as 7,000 ft (McIntyre, 1979). Low concentration of magnesium in the thermal waters seems to favor silicic volcanic rocks as the principal reservoir rock in the regional thermal ground-water system. Due to head differentials, some thermal water probably moves upward into the overlying Banbury Basalt.

A system of northwest-trending faults, particularly in the northern part of the area, has fractured and displaced the rock units. Most of the faulting probably occurred in early Pliocene time and progressively diminished through Pleistocene time.

Thermal ground water in southwestern Idaho and north-central Nevada generally occurs under artesian conditions in both the volcanic and sedimentary rocks. The artesian head is variable and may range from a few feet above the water-bearing zone to several hundred feet above land surface. Generally, large well yields and hightemperature waters are from wells penetrating the volcanic-rock aquifers. These wells range from 600 to $3,600 \mathrm{ft}$ in depth, and the water temperatures range from about $30^{\circ} \mathrm{C}$ to more than $80^{\circ} \mathrm{C}$. Wells penetrating the sedimentary-rock aquifers yield smaller amounts of lower temperature water.

Climate in most of the area is semiarid. Plateau and valley areas receive less than 15 in. of precipitation annually (Thomas and others, 1963). The highest parts of the Owyhee and Jarbidge Mountains to the south receive as much as $50 \mathrm{in}$. annually and may be the recharge areas for the thermal aquifers.

\section{GEOCHEMICAL CHARACTERISTICS OF THE HYDROTHERMAL SYSTEM}

\section{CHEMICAL CHARACTER}

Water samples for chemical analyses were obtained from 12 wells and 9 springs. Results of the analyses are included in table 1. Additional chemical analyses of thermal and nonthermal waters from the area are given in Rightmire, Young, and Whitehead (1976, table 2). Generally, the waters may be divided into three principal types on the basis of proportions of major dissolved constituents and concentration of dissolved solids: (1) Nonthermal water from springs, located mostly at high altitudes in the Owyhee and Jarbidge Mountains to the south, (2) hot water from springs and wells, and (3) warm water from springs and wells, probably representing a mixture of hot water and cooler, local ground waters.

The nonthermal waters are generally calcium bicarbonate in character. Only one spring water exceeded a dissolved-solids concentration of $120 \mathrm{mg} / \mathrm{L}$. All other nonthermal waters sampled had a concentration of dis- 
TABLE 1. -Chemical analyses of water from selected wells and springs

[Chemical constituents in milligrams per liter, except where noted. a, approximate; --, no data reported; c, less than]

\begin{tabular}{|c|c|c|c|c|c|c|c|c|c|c|c|c|c|c|c|c|c|c|c|c|c|c|c|c|c|c|c|c|}
\hline 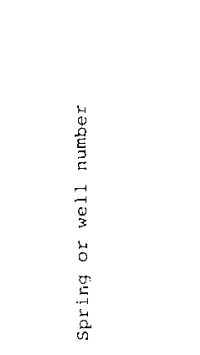 & 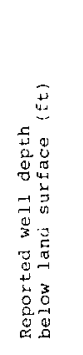 & 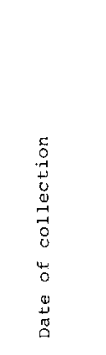 & 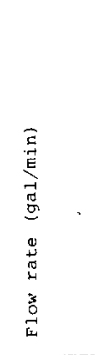 & 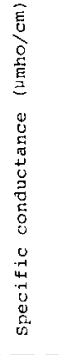 & 票 & 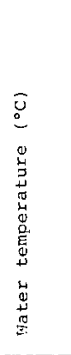 & 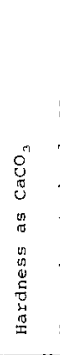 & 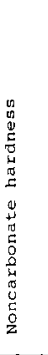 & 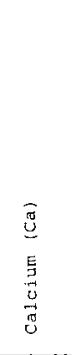 & 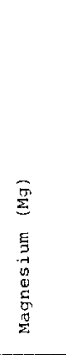 & 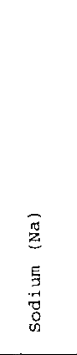 & 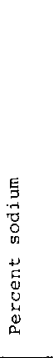 & 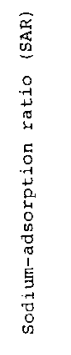 & 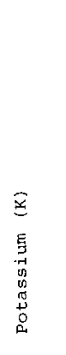 & 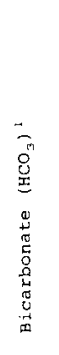 & 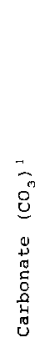 & 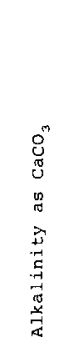 & 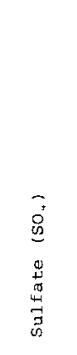 & 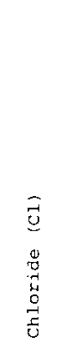 & $\begin{array}{l}\bar{E} \\
\bar{g} \\
\overline{\tilde{g}} \\
\vec{g} \\
\vec{m}\end{array}$ & 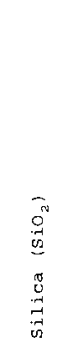 & 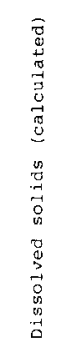 & 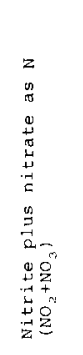 & 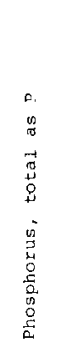 & 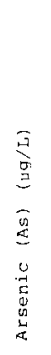 & 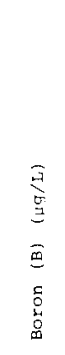 & 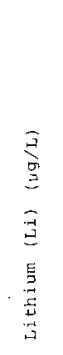 & 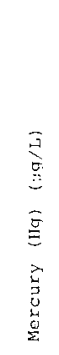 \\
\hline \multicolumn{29}{|c|}{ Nonthermal sources } \\
\hline $6 S-2 W-14 C B A 1 S^{2}$ & & $7-2-73$ & 27 & 91 & 7.1 & 11.0 & 20 & 0 & 5.6 & 1.4 & 8.2 & 14 & 0.8 & 2.0 & 28 & 0 & 23 & 8.5 & 6.3 & 0.1 & 30 & 86 & 2.3 & 0.06 & 1 & 30 & 0 & 0.2 \\
\hline$B S-1 E-20 C C A 15^{2}$ & & $7-2-73$ & 4 & 100 & 7.1 & 9.5 & 39 & 0 & 11 & 2.8 & 6.0 & 25 & .4 & .7 & 62 & 0 & 51 & 3.2 & 2.0 & .2 & 22 & 81 & .62 & .07 & 2 & 20 & 0 & .I \\
\hline $95-2 E-13 \mathrm{CBC} 15^{2}$ & & $7-2-73$ & 4 & 130 & 7.2 & 11.0 & 47 & 0 & 14 & 29 & 11 & 33 & .7 & 2.1 & 71 & 0 & 58 & 9.5 & 6.3 & .3 & 39 & 120 & .04 & .08 & $<1$ & 40 & 0 & .3 \\
\hline $11 \mathrm{~S}-5 \mathrm{~N}-2 \mathrm{DAB} 1 \mathrm{~S}$ & & $6-13-78$ & 10 & 74 & 7.3 & 7.5 & 15 & 0 & 4.3 & 1.0 & 6.0 & 43 & .7 & 1.9 & 21 & 0 & 17 & 3.4 & 2.1 & .2 & 32 & 61 & 2.5 & .01 & 1 & 30 & 5 & $<1$ \\
\hline 138. $\quad 4 \mathrm{~L}-12 \mathrm{CDD} 1$ & .. & $6-15-78$ & $2 a$ & 140 & 7.0 & 8.0 & 34 & 1 & 10 & 2.1 & 10 & 36 & .8 & 4.4 & 40 & 0 & 33 & 7.8 & 18 & .2 & 35 & 107 & .55 & .06 & 1 & $5 n$ & 9 & $<.1$ \\
\hline $14 S-14 \mathrm{E}-11 \mathrm{CAB} 1 \mathrm{~S}$ & & $6-27-78$ & $1.000 a$ & 91 & 7.0 & 12.0 & 23 & 0 & 7.2 & 1.2 & 5.9 & 33 & .5 & 2.6 & 30 & 0 & 25 & 5.0 & 3.1 & .2 & 35 & 75 & .89 & .03 & 1 & 20 & 4 & $\therefore 1$ \\
\hline $46 \mathrm{~N}-60 \mathrm{E}-13 \mathrm{ACC} 1 \mathrm{~S}$ & & $6-27-78$ & 10 & 35 & 6.1 & 4.0 & 5 & 0 & 1.9 & $<.1$ & 1.7 & 31 & .3 & 2.8 & 13 & 0 & 11 & 2.7 & .4 & .1 & 33 & 49 & .04 & .01 & $<1$ & $?$ & 2 & $\therefore 1$ \\
\hline $45 \mathrm{~N}-55 \mathrm{E}-25 \mathrm{DAA}_{1} \mathrm{~S}$ & & $6-28-78$ & 24 & 419 & 7.3 & 6.5 & 240 & 16 & 65 & 19 & 3.8 & 3 & .1 & .6 & 270 & 0 & 220 & 7.7 & 1.8 & .1 & 13 & 243 & .41 & 0.01 & $<1$ & 20 & 10 & $\therefore 1$ \\
\hline \multicolumn{29}{|c|}{ Thermal sources } \\
\hline $1 \mathrm{ii}-3 \mathrm{iW}-21 \mathrm{ACD} 1 \mathrm{~S}$ & & $6-14-78$ & 4 & 540 & 9.2 & 56.0 & 7 & 0 & 3.0 & 0.1 & 130 & 97 & 22 & 2.0 & 140 & 38 & 180 & 41 & 24 & 3.3 & 89 & 410 & 0.04 & 0.01 & 1 & 230 & 9 & 0.1 \\
\hline $1 s-2 \mathrm{~W}-7 \mathrm{CCB} 1$ & 1,700 & $6-13-78$ & 120 & 545 & 9.2 & 45.0 & 4 & 0 & 1.4 & $<.1$ & 130 & 98 & 30 & 1.2 & 140 & 30 & 160 & 45 & 22 & 12 & 61 & 369 & 03 & .01 & 2 & 250 & 10 & $\cdots$ \\
\hline $2 S-2 W-35 A C B 1$ & 1,187 & $6-13-78$ & $1,700 a$ & 438 & 9.6 & 40.0 & 10 & 0 & 3.9 & $<.1$ & 99 & 95 & 14 & 2.0 & 71 & 48 & 140 & 59 & 8.7 & 2.7 & 84 & 342 & .03 & .02 & 7 & 110 & 5 & 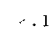 \\
\hline$\therefore S-1 E-34$ BADI & 2,980 & $6-13-78$ & 351 & 430 & 9.2 & 76.5 & 3 & 0 & 1.1 & $<.1$ & 110 & 98 & 29 & .8 & 78 & 38 & 130 & 40 & 16 & 13 & 77 & 336 & .04 & .01 & 30 & $15 c$ & 17 & $\cdots$ \\
\hline $5 S-4 W-8 A D A 1$ & 2,000 & $6-13-78$ & $240 a$ & 206 & 7.5 & 20.0 & 36 & 8 & 13 & .9 & 16 & 44 & 1.2 & 6.2 & 34 & 0 & 28 & 51 & 1.0 & .5 & 43 & 148 & .04 & .04 & 13 & 20 & 40 & $\cdots$ \\
\hline $5 S-3 E-26 B C B 1$ & 2,970 & $6-13-78$ & 100 & 529 & 9.3 & 81.0 & 6 & 0 & 2.4 & $\times .1$ & 120 & 97 & 21 & 1.7 & 48 & 48 & 120 & 74 & 15 & 15 & 110 & 410 & .08 & .01 & 4 & 550 & 40 & $\cdots 1$ \\
\hline $75-5 E-7 A B B=$ & 1,625 & $6-13-78$ & 3,080 & 277 & 8.7 & 39.5 & 17 & 0 & 6.7 & $<.1$ & 52 & 81 & 5.5 & 7.2 & 83 & 7 & 80 & 18 & 8.9 & 9.4 & 77 & 227 & .33 & .01 & 14 & 100 & 9 & $\cdots 1$ \\
\hline $75-6 \mathrm{E}-9 \mathrm{BADI}$ & 910 & $6-13-78$ & 120 & 433 & 9.4 & 51.0 & 5 & 0 & 2.1 & $<.1$ & 100 & 96 & 19 & 2.8 & 56 & 46 & 120 & 28 & 9.7 & 23 & 87 & 325 & .04 & .01 & 30 & 220 & 20 & $\therefore 1$ \\
\hline $8 S-14 E-30 A C D 1 S$ & & $2-8-78$ & 40 & 601 & 9.1 & 70.5 & 3 & 0 & 1.2 & $<.1$ & 140 & 99 & 35 & 1.1 & 70 & 45 & 130 & 32 & 50 & 2.7 & 89 & 418 & .06 & .01 & 60 & 440 & 60 & .1 \\
\hline $9 \mathrm{~S}-13 \mathrm{E}-33 \mathrm{CBD} 1$ & 840 & $6-26-78$ & $1,200 \mathrm{a}$ & 326 & 8.0 & 30.0 & 81 & 0 & 26 & 3.9 & 35 & 46 & 1.7 & 7.9 & 120 & 0 & 98 & 35 & 16 & 1.8 & 86 & 270 & 1.0 & $<.01$ & 9 & 60 & 50 & $\therefore, 1$ \\
\hline $12 \mathrm{~S}-7 \mathrm{E}-33 \mathrm{CBC} 1 \mathrm{~S}$ & & $6-15-78$ & 1,900 & 345 & 9.4 & 71.5 & 3 & 0 & 1.3 & $<.1$ & Bo & 98 & 19 & .8 & 56 & 36 & 110 & 23 & 9.1 & 16 & 71 & 267 & .02 & .01 & 16 & 110 & 60 & $<.1$ \\
\hline $14 S-9 E-2 B A A I$ & 953 & $6-27-78$ & $32 \mathrm{a}$ & 358 & 7.9 & 26.5 & 120 & 5 & 31 & 10 & 30 & 34 & 1.2 & 5.4 & 140 & 0 & 120 & 32 & 19 & 1.0 & 71 & 271 & 3.1 & .01 & 9 & 70 & 20 & $\therefore 1$ \\
\hline $16 S-9 E-24 B B 1 S$ & & $6-28-78$ & 80 & 128 & 8.5 & 54.5 & 15 & 0 & 5.9 & $<.1$ & 30 & 79 & 3.4 & 2.1 & 56 & 5 & 54 & 4.7 & 2.0 & 3.6 & 120 & 201 & .21 & .05 & 9 & 30 & 30 & $\therefore 1$ \\
\hline $47 i v-65 \mathrm{~L}-17 \mathrm{CBCl}$ & 1,280 & $12-7-77$ & -- & 322 & 7.3 & 36.0 & 130 & 0 & 38 & 9.2 & 18 & 21 & .7 & 8.9 & 180 & 0 & 150 & 22 & 2.5 & .7 & 20 & 209 & .15 & $<.01$ & 1 & 30 & 60 & $\therefore 1$ \\
\hline $46: N-64 E-23 D B D 1 S$ & & $4-26-79$ & 20 & 262 & 7.5 & 24.0 & 88 & 0 & 23 & 7.3 & 14 & 25 & .7 & 4.5 & 140 & 0 & 110 & 37 & 4.0 & .1 & 16 & 152 & .16 & $<.01$ & 15 & 160 & 30 & $\cdots$ \\
\hline $45 N-64[-20 A C B 1$ & - & $4-26-79$ & -- & 380 & 8.8 & 54.0 & 8 & 0 & 2.4 & .6 & 78 & 94 & 12 & 2.4 & 78 & 17 & 92 & 49 & 11 & 8.8 & 75 & 282 & $\therefore .01$ & .01 & 2 & 530 & 160 & $\cdots 1$ \\
\hline
\end{tabular}

1 Total alkalinity distributed as carbonate and bicarbonate at the spring or well water temperature and pH.
\&igitmire, Young, and whitehead (1976). 
solved solids of $120 \mathrm{mg} / \mathrm{L}$ or less. Hot waters do not seem to be mixed and are, therefore, representative of the hottest water from the deep convective system. These waters are generally sodium carbonate or bicarbonate in character, having concentrations of dissolved solids less than about $400 \mathrm{mg} / \mathrm{L}$. Concentrations of chloride and fluoride in the $80^{\circ} \mathrm{C}$ water are about $15 \mathrm{mg} / \mathrm{L}$; concentration of boron is about $550 \mu \mathrm{g} / \mathrm{L}$.

Warm waters are mostly sodium bicarbonate in character, and the concentration of dissolved solids is generally less than about $300 \mathrm{mg} / \mathrm{L}$. In the vicinity of Oreana and Grand View, however, warm waters sampled by Rightmire, Young, and Whitehead (1976) had concentrations of dissolved solids as high as $1,160 \mathrm{mg} / \mathrm{L}$. All the warm waters that had high concentrations of dissolved solids were sampled from wells producing from sedimentary rocks of the Idaho Group.

The relatively dilute nature, the wide range in concentration of dissolved solids, and the variability in concentrations of chloride and boron in all the thermal waters indicate a large, complex, interconnected hydrologic system. The vertical multiplicity of aquifers, along with areal compartmentalization created by faulting, present an almost infinite number of avenues for deep circulation of thermal water. The depths and duration of circulation, contact with different rock types, and mixing with shallow, local ground waters serve to produce the variations in temperature and water chemistry evident in the thermal waters.

\section{CHEMICAL GEOTHERMOMETERS}

Reservoir temperatures estimated using the silica and $\mathrm{Na}-\mathrm{K}$-Ca geothermometers are valid only for hot-water systems and only if the following basic assumptions are met: (1) The chemical reactions at depth are temperature dependent; (2) an adequate supply of chemical constituents used for the thermometry is present in the aquifer; (3) chemical equilibrium is established between the hot water and the specific aquifer minerals; (4) reequilibration of the chemical composition of hot water as it rises to the surface is negligible; and (5) hot water rises rapidly to the surface with no dilution or mixing of hot and cold waters (White, 1970).

Reservoir temperatures in the study area were estimated using the silica geothermometer (Fournier and Rowe, 1966) and the Na-K-Ca geothermometer (Fournier and Truesdell, 1973). Silica equilibrium with both quartz and chalcedony was considered assuming conductive heat loss. No magnesium correction was applied because the $\mathrm{Na}-\mathrm{K}-\mathrm{Ca}$ geothermometer indicated temperatures of $74^{\circ} \mathrm{C}$ or less for samples containing appreciable (greater than $1 \mathrm{mg} / \mathrm{L}$ ) magnesium. (Fournier and Potter (1979) suggested that a magnesium correction should not be attempted if the $\mathrm{Na}-\mathrm{K}-\mathrm{Ca}$ geothermometer indicates a temperature of less than $70^{\circ} \mathrm{C}$.)

Dissolved silica $\left(\mathrm{SiO}_{2}\right)$ reported in chemical analyses is actually present as silicic acid $\left(\mathrm{H}_{4} \mathrm{SiO}_{4}\right)$ and various amounts of dissociated species (particularly $\mathrm{H}_{3} \mathrm{SiO}_{4}^{-}$). In alkaline waters, hydroxide $\left(\mathrm{OH}^{-}\right)$reacts with the silicic acid to reduce the proportion of silicic acid to total dissolved silica:

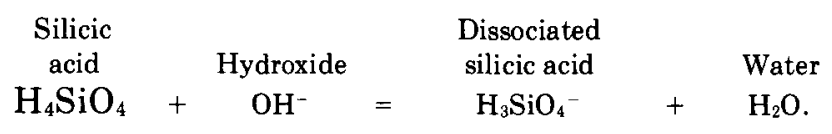

The $\mathrm{pH}$ of thermal waters sampled ranged from 7.3 to 9.6. For waters that have $\mathrm{pH}$ values greater than about 8.2 , the total concentration of dissolved silica measured in the laboratory $\left(\mathrm{H}_{4} \mathrm{SiO}_{4}+\mathrm{H}_{3} \mathrm{SiO}_{4}^{-}\right)$was reduced by the calculated concentration of $\mathrm{H}_{3} \mathrm{SiO}_{4}{ }^{-}$to obtain a better estimate of the temperature of the thermal reservoir (Brook and others, 1979).

Estimated reservoir temperatures for 11 hot-water wells and 5 hot springs sampled in the study area are given in table 2. Locations of the sample sites are shown on plate 2. In general, most of the temperatures estimated using the $\mathrm{Na}-\mathrm{K}-\mathrm{Ca}$ and the $\mathrm{H}_{3} \mathrm{SiO}_{4}^{-}$corrected quartz geothermometers are in good agreement. Temperatures estimated using the $\mathrm{H}_{3} \mathrm{SiO}_{4}^{-}$corrected chalcedony geothermometers generally are less than temperatures estimated using the $\mathrm{Na}-\mathrm{K}-\mathrm{Ca}$ geothermometer and, occasionally, were less than the water temperature measured at the surface.

Figure 2 is a comparison of reservoir temperatures estimated by the $\mathrm{H}_{3} \mathrm{SiO}_{4}{ }^{-}$corrected quartz and $\mathrm{Na}-\mathrm{K}-\mathrm{Ca}$ geothermometers. Waters that plot on or very near the equal-temperature line are likely to be unmixed waters or waters that have reequilibrated with the aquifer minerals after mixing (Fournier and others, 1979). If the calculated temperature is significantly higher than the measured temperature for these unmixed or reequilibrated waters, some heat has probably been lost conductively as the water moves through the aquifer.

Waters that plot significantly above the equaltemperature line have undergone evaporation or contain silica dissolved from amorphous aquifer material. The $\mathrm{Na}-\mathrm{K}-\mathrm{Ca}$ geothermometer uses ratios of constituents and is less sensitive to concentration changes that occur during evaporation than is the silica geothermometer.

Waters that plot significantly below the equaltemperature line may have had (1) mixing with another type water without sufficient time to equilibrate with the surrounding rock (in mixed waters, silica estimated temperatures are generally decreased more than Na-K- 
TABLE 2.-Estimated reservoir temperatures and free energy of formation for selected hot-water wells and hot springs

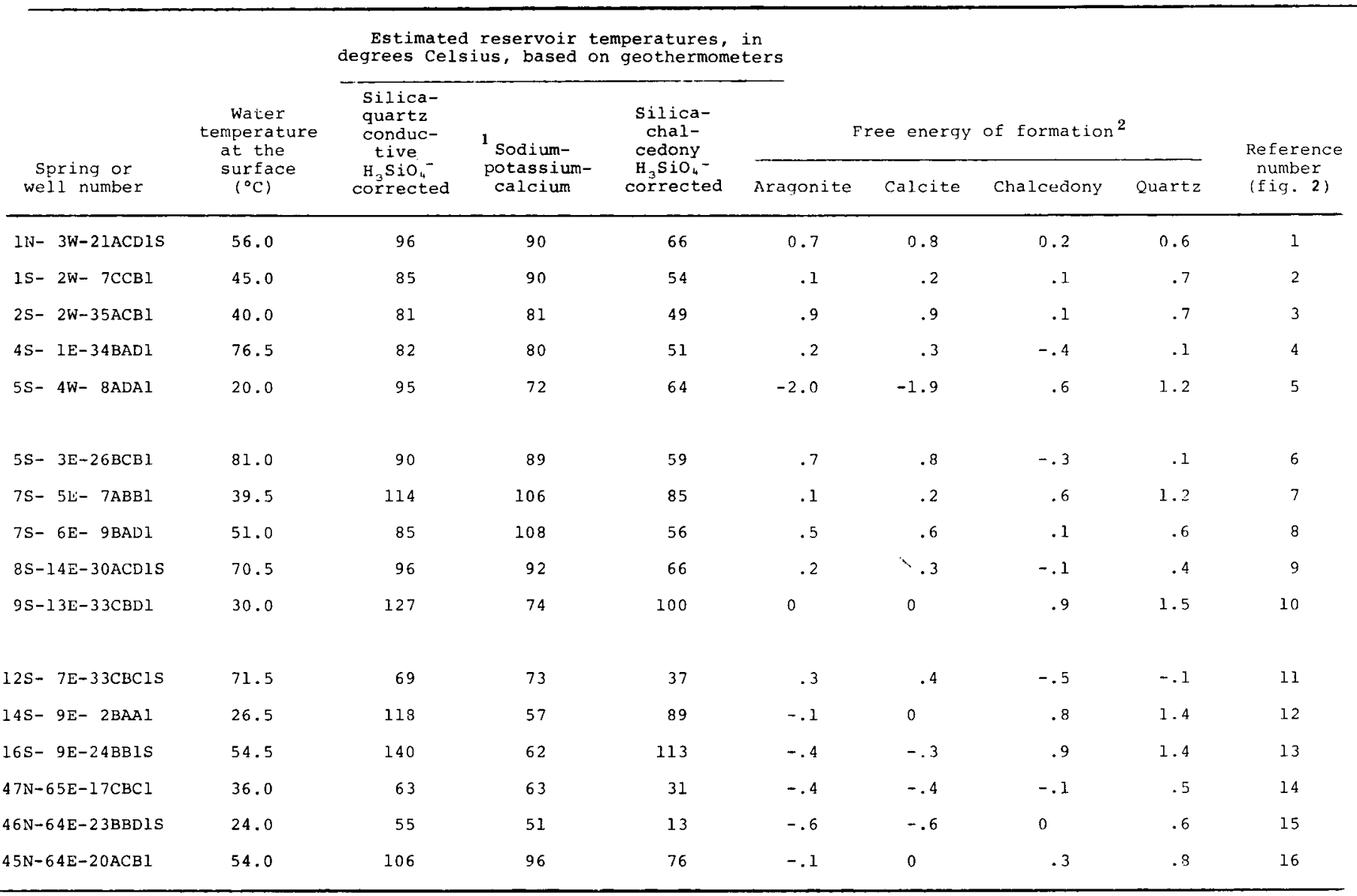

${ }^{1}$ Temperatures calculated using $\beta=1 / 3$ (Fournier and Truesdell, 1973).

${ }^{2}$ Values are departure from theoretical equilibrium in kilocalories; $(+)$ values indicate supersaturated, $(-)$ values indicate unsaturated. Calculations from computer program SOLMNEQ (Kharaka and Barnes, 1973).

Ca estimated temperatures), (2) precipitation of silica during cooling, whereas $\mathrm{Na}-\mathrm{K}-\mathrm{Ca}$ proportions remain unchanged, or (3) precipitation of calcite or aragonite due to loss of carbon dioxide without an adjustment in the concentration of sodium and potassium through reaction with clays, zeolites, or other minerals (Fournier and others, 1979).

As shown in figure 2, most sampled waters plot on or near the equal-temperature line and are probably unmixed waters or waters that have had time to reequilibrate with the surrounding waters after mixing. Estimated reservoir temperatures between Givens Hot Springs and Murphy (sample Nos. 1, 2, and 3) range from $81^{\circ}$ to $96^{\circ} \mathrm{C}$. Estimated reservoir temperatures in the area between Oreana and Grand View (sample Nos. 4 and 6) range from $80^{\circ}$ to $90^{\circ} \mathrm{C}$. Reservoir-temperature estimates for spring $12 \mathrm{~S}-7 \mathrm{E}-33 \mathrm{CBC} 1 \mathrm{~S}$ (sample No. 11) are within $2^{\circ}$ of the temperature of $71.5^{\circ} \mathrm{C}$ measured at the surface. Estimated reservoir temperatures for the two hot-water wells and one warm spring (sample Nos. 14, 15, and 16) in north-central Nevada were in good agreement at each location, although the estimated temperatures at the three sites ranged from $51^{\circ}$ to $106^{\circ} \mathrm{C}$. Reservoir temperatures near Buhl (sample No. 9) range from $92^{\circ}$ to $96^{\circ} \mathrm{C}$.

Samples $5,10,12$, and 13 (significantly above the equal-temperature line) may have undergone evaporation, or dissolution of vitreous material in the aquifer may have increased the dissolved silica concentration. The $\mathrm{Na}-\mathrm{K}-\mathrm{Ca}$ geothermometer temperatures are probably the better estimate because of the unsaturation of calcite or aragonite (table 2). Samples 7 and 8 (below the equal-temperature line) probably indicate a mixed water that has not reequilibrated chemically with the aquifer materials after mixing.

Reservoir temperatures were estimated for samples 4 , 


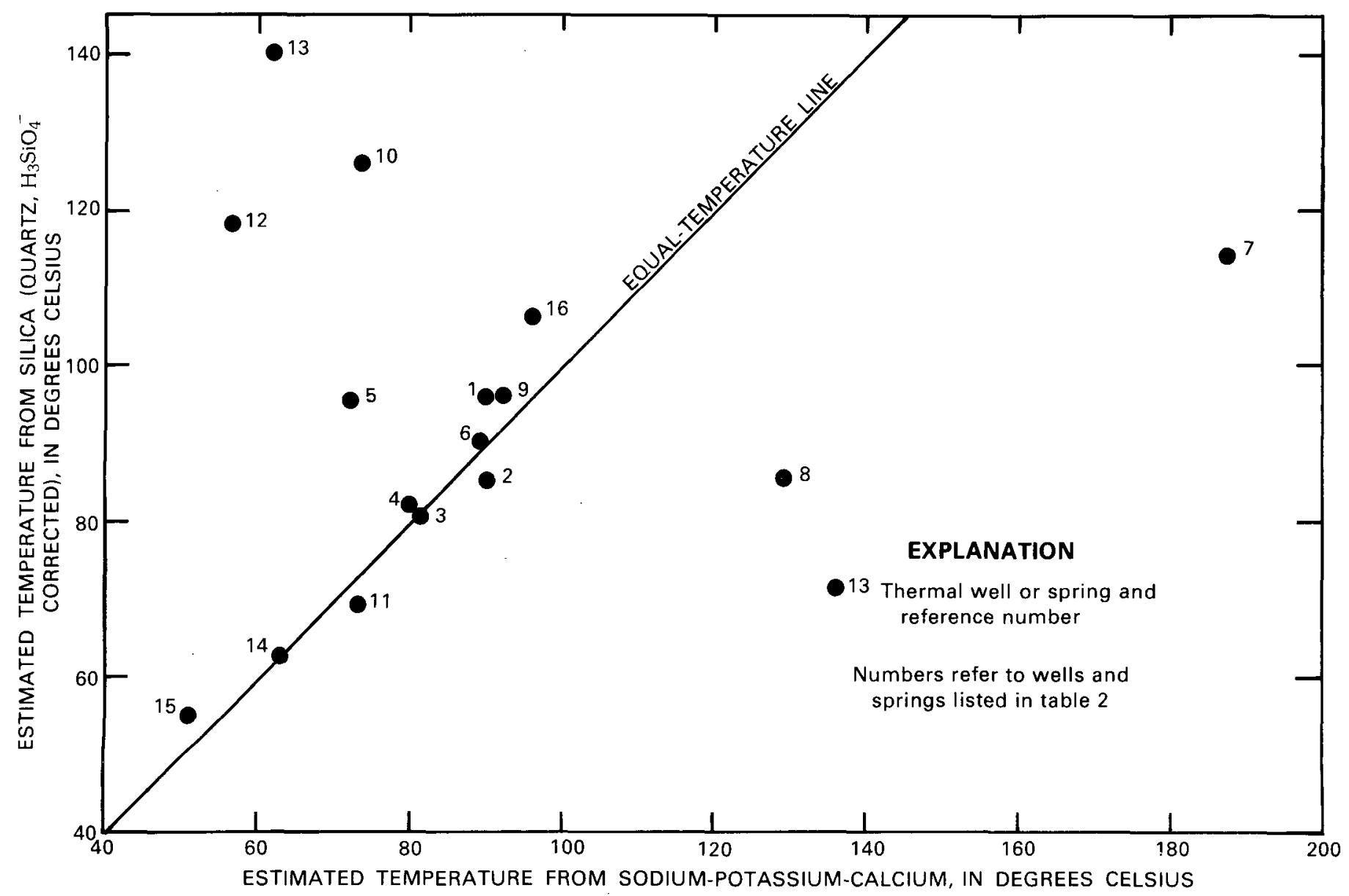

FIGURE 2.-Comparison of reservoir temperatures estimated by the silica and sodium-potassium-calcium geothermometers.

6,7 , and 11 , using the sulfate-water isotope geothermometer described by McKenzie and Truesdell (1977). Assuming conductive heat loss, N. L. Nehring, U.S. Geological Survey, Menlo Park, Calif., determined reservoir temperatures of $103^{\circ}, 95^{\circ}, 106^{\circ}$, and $115^{\circ} \mathrm{C}$ for samples $4,6,7$, and 11 , respectively (table 2 ).

Dissolved sulfate and water are probably in isotopic equilibrium in all reservoirs of significant size having temperatures above about $140^{\circ} \mathrm{C}$ (McKenzie and Truesdell, 1977). The reasonably close agreement of the sulfate-water isotope geothermometer temperatures obtained for three of the waters with those obtained using the silica and $\mathrm{Na}-\mathrm{K}-\mathrm{Ca}$ geothermometers may indicate that, given sufficient residence time, equilibrium could also be achieved in reservoirs at a temperature as low as $100^{\circ} \mathrm{C}$.

On the basis of available geothermometry, estimated reservoir temperatures in southwestern Idaho probably range from about $80^{\circ}$ to near $100^{\circ} \mathrm{C}$. Reservoir temperatures in north-central Nevada probably range from $51^{\circ}$ to $106^{\circ} \mathrm{C}$.

\section{ISOTOPES}

Samples of thermal and nonthermal water from 7 wells and 5 springs were obtained for analysis of tritium, deuterium, and oxygen-18. Several conclusions may be drawn concerning age, origin, and mixing patterns of the geothermal water on the basis of these analyses.

\section{TRITIUM}

Tritium $\left({ }^{3} \mathrm{H}\right)$ is a radioactive isotope of hydrogen and decays with a half-life of about 12.4 years. It is formed in the upper atmosphere during bombardment by subatomic particles from outer space and is introduced into the water cycle dissolved in rain and snow. Although concentrations of tritium in precipitation vary both seasonally and geographically, prior to extensive thermonuclear testing between 1953-63, average tritium levels in precipitation were about $10^{-18} \mathrm{TU}$ (tritium units). (One TU equals a ${ }^{3} \mathrm{H} / \mathrm{H}$ ratio of about $10^{-18}$, or about $3.2 \times 10^{-18}$ picocuries per liter.) By 1963 , worldwide 
tritium levels in precipitation had increased several orders of magnitude and were reported to be 7,000 TU in the vicinity of Yellowstone National Park (Pearson and Truesdell, 1978). Since the ending of atmospheric nuclear tests, tritium levels in precipitation have declined and presently (1979) average about $50 \mathrm{TU}$.

Tritium content in ground water is a function of tritium content in the recharge water and the residence time and nature of flow in the system. Two basic types of flow models were discussed in detail by Nir (1964): (1) the piston-flow model, which has parallel flow lines of constant and equal velocity, so that a water sample taken at some point would include only water originating at the point of recharge; and (2) the completely mixed reservoir model, where it is assumed that the recharge water is continually and instantly mixing throughout the entire system. Tritium content in water of various residence times, assuming piston-flow and well-mixed reservoir systems, in Yellowstone National Park was calculated by Pearson and Truesdell (1978) and is shown in figure 3. Curves similar to those in figure 3 probably would result for comparable ground-water systems in thermal areas of southwestern Idaho and north-central Nevada.

Results of tritium analyses of water samples from selected wells and springs are shown in table 3 . Samples

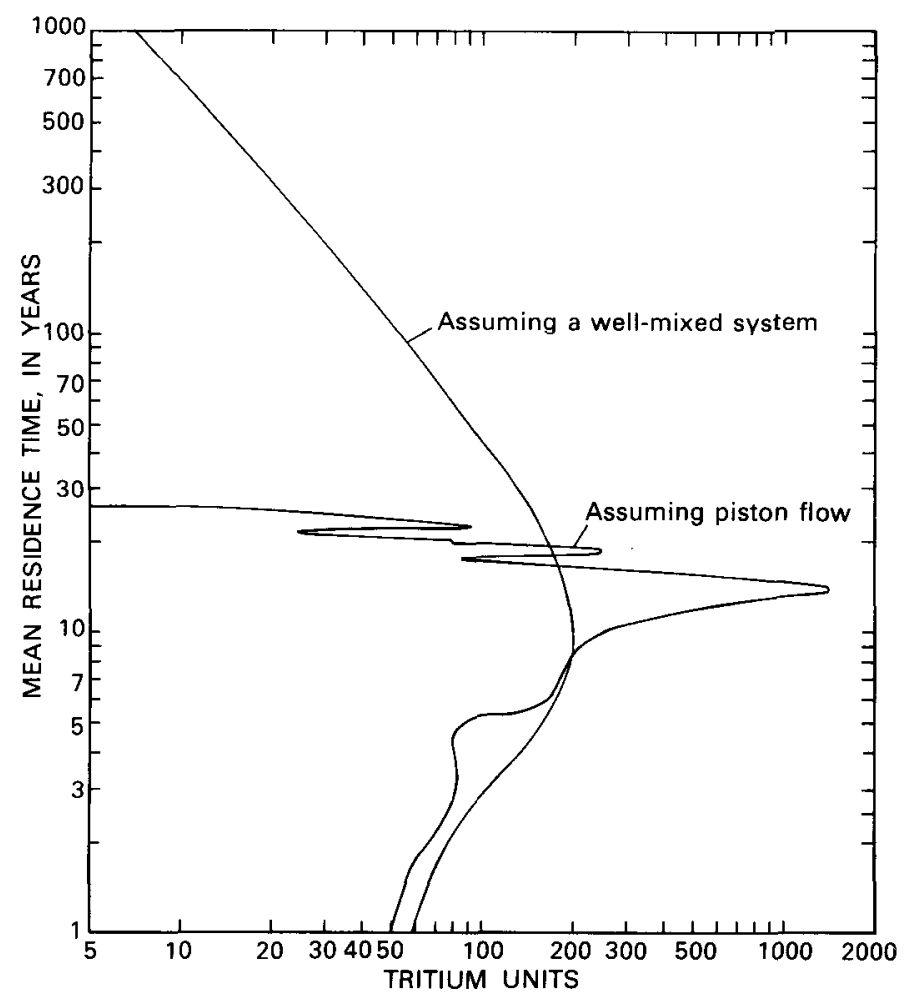

FIgURE 3.-Tritium content of water assuming piston-flow and wellmixed ground-water systems in Yellowstone National Park (from Pearson and Truesdell, 1978). analyzed in the Reston, Va., laboratory of the U.S. Geological Survey were predistilled and enriched by electrolysis. Enriched aliquots from the $100-\mathrm{mL}$ (milliliter) samples were counted by a liquid scintillation counter; enriched aliquots of $470-\mathrm{mL}$ samples were counted by a gas proportional counter. In table 3 errors are given for one standard deviation and include those incurred during radioactive counting, as well as volume errors. For the $100-\mathrm{mL}$ enrichment method of analysis, the minimum error is $0.6 \mathrm{TU}$; for the $470-\mathrm{mL}$ enrichment method, the minimum error is $0.2 \mathrm{TU}$. All samples were corrected for tritium decay to the collection date using a half-life of 12.361 years.

As shown in table 3, concentration of tritium in water sampled from wells and springs having temperatures between $51^{\circ}$ and $81^{\circ} \mathrm{C}$ ranges from 0 to $1.4 \mathrm{TU}$. Concentration of tritium in water sampled from two

TABLE 3.-Tritium in water from selected wells and springs

$\begin{array}{llc} & \text { Water } & \\ \text { temperature } & \\ \text { Well or spring } & \text { at surface } & \text { Tritium } \\ \left({ }^{\circ} \mathrm{C}\right) & \text { (TU) }\end{array}$

NONTHERMAL

$\begin{array}{lrr}11 S-5 W-2 D A B 1 S & 7.5 & 284 \\ 13 S-4 E-12 C D D 1 & 8.0 & 267 \\ 14 S-14 E-11 C A B 1 S & 12.0 & 295 \\ 46 N-60 E-13 A C C 1 S & 4.0 & 259 \\ 45 N-55 E-25 D A A 1 S & 6.5 & 2119\end{array}$

THERMAL

$\begin{array}{lll}1 N-3 W-21 A C D 1 S & 56.0 & { }^{1} 0 \pm 0.2 \\ 4 S-1 E-34 \mathrm{BAD} I & 76.5 & { }^{1} 1.4 \pm 0.6 \\ 5 S-4 W-8 \mathrm{ADA} I & 20.0 & 21.9 \\ 5 S-3 E-26 \mathrm{BCB} 1 & 81.0 & { }^{1} 0 \pm 0.2 \\ 7 S-5 E-7 \mathrm{ABB} 1 & 39.5 & { }^{1} 0.9 \pm 0.6 \\ 7 S-6 E-9 B A D 1 & 51.0 & { }^{1} 0 \pm 0.2 \\ 16 S-9 E-24 \mathrm{BB} 1 S & 54.5 & { }^{1} 0.5 \pm 0.6\end{array}$

${ }^{\lrcorner}$Samples analyzed by T. A. Wyerman, U.S. Geological Survey, Reston, Va.

2Samples analyzed in U.S. Geological Survey Central Laboratory, Arvada, Colo. 
cold-water springs in the Jarbidge Mountains to the south was 59 and 119 TU. Tritium in water from a slightly thermal $\left(20^{\circ} \mathrm{C}\right)$ well was $1.9 \mathrm{TU}$. Considering the standard deviation of the 100 - and $470-\mathrm{mL}$ aliquots, it is unlikely that any of the water sampled from the hot wells and springs contains significant amounts of post-1954 water. This conclusion is based on an estimate of pre1954 precipitation at $10 \mathrm{TU}$ and about two half-lives decay. The actual choices concerning the origins of the hot water are either all pre-1954 precipitation or considerably older water that has small amounts of post1954 precipitation (T. A. Wyerman, written commun., 1979). Some degree of mixing, therefore, is not absolutely precluded from the tritium data. From the small amount of tritium in the hot water sampled, residence time in the system is at least 30 years.

Regarding the high concentration of tritium in the cold spring water to the south, a residence time of as little as 2 years or as many as 20 years is indicated (fig. 3), assuming piston flow in the system; for a well-mixed reservoir, residence time up to 20 years may be possible. If the warm water is unmixed and has a tritium concentration of $1.9 \mathrm{TU}$, using the piston-flow model, a residence time of about 30 years is indicated.

\section{DEUTERIUM AND OXYGEN-18}

Concentration of the stable isotopes, deuterium (D) and oxygen-18 $\left({ }^{18} \mathrm{O}\right)$, in water from different sources is used to characterize and indicate the origin and mixing patterns of individual waters.

Principal stable molecular species in water are $\mathrm{H}_{2}{ }^{16} \mathrm{O}$, $\mathrm{H}_{2}{ }^{17} \mathrm{O}, \mathrm{H}_{2}{ }^{18} \mathrm{O}$, and $\mathrm{HDO}$. In ocean water, the proportions of these species are $10^{6}: 2,000: 420: 316$ (Craig, 1963); this composition is referred to as SMOW (standard mean ocean water). Atmospheric water derived from the ocean is depleted in the stable isotopes. The isotopic composition of precipitation depends on the fraction of water remaining in the air mass from which the rain or snow is derived, the first precipitation being the richest in heavy isotopes (Ellis and Mahon, 1977). Stableisotope concentrations are generally expressed in delta units $(\delta)$ and are reported in parts per mil $(\%)$, or parts per thousand. These units represent relative deviations in the heavy isotope fraction in water and are defined as

$$
\delta=\left[\frac{\mathrm{R}_{\text {sample }}-R_{\text {standard }}}{\mathrm{R}_{\text {standard }}}\right] \times 1,000,
$$

where

$$
\begin{array}{r}
\mathrm{R}_{\text {sample }}=\text { ratio or isotopic concentration } \\
\left({ }^{18} \mathrm{O} /{ }^{16} \mathrm{O}, \mathrm{D} / \mathrm{H}\right) \text { of the sample, }
\end{array}
$$

and

$$
\begin{gathered}
R_{\text {standard }}=\text { ratio of isotopic concentration } \\
\text { of the standard SMOW. }
\end{gathered}
$$

A worldwide study of freshwater samples by Craig (1963) showed that the isotopic compositions of cold meteoric waters were related by the equation $\delta \mathrm{D}=8 \delta^{18} \mathrm{O}+10$. This straight line, commonly referred to as the meteoric water line, is shown in figure 4; the slope of the line may vary regionally: Depletion of stable isotopes in meteoric waters (reporting units become more negative) in general can be correlated with distance from the ocean, latitude, and altitude (or temperature). Waters affected by extensive nonequilibrium evaporation, as in inland basins, lie off the meteoric line. However, at ordinary air tempertures, evaporated surface waters are connected approximately to the original precipitation composition $\delta^{18} \mathrm{O}_{0}, \delta \mathrm{D}_{\mathrm{o}}$ by a line expressing the equation $\delta \mathrm{D}=5\left(\delta^{18} \mathrm{O}-\delta^{18} \mathrm{O}_{\mathrm{o}}\right)+\mathrm{D}_{\mathrm{o}}$ (Ellis and Mahon, 1977).

During passage through an aquifer, thermal and nonthermal ground water retains the $\mathrm{D}$ composition characteristic of precipitation in the recharge area. A comparable hydrogen-isotope shift does not occur because rock

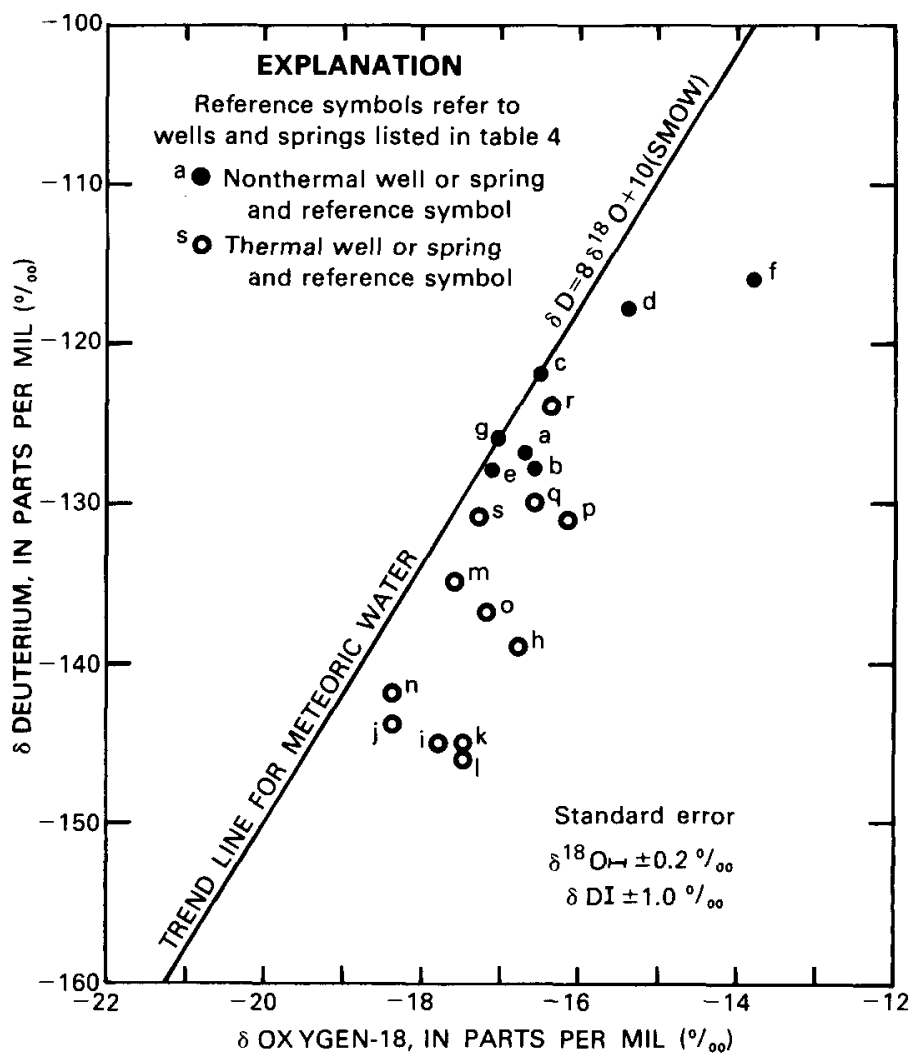

FIGURE 4.--Relations between concentrations of deuterium and oxygen-18. 
minerals contain little hydrogen and because the water to rock ratios of geothermal systems are seldom so low that the hydrogen of rock minerals is a significant fraction of the total hydrogen (Truesdell and Hulston, 1980). However, hydrogen and oxygen isotope-exchange reactions between clay minerals and water have been observed by $0^{\prime} N$ Neil and Kharaka (1976) in laboratory bomb runs at temperatures between $100^{\circ}$ and $150^{\circ} \mathrm{C}$. The ${ }^{18} \mathrm{O}$ content in thermal water is usually enriched (becomes less negative) to varying degrees during circulation within the system, due to reaction with the more enriched ${ }^{18} \mathrm{O}$ of the confining rock. Isotope-exchange reactions between water and rock occur slowly at temperatures below $150^{\circ} \mathrm{C}$ (Hobba and others, 1979) and are generally detected only in systems having reservoir temperatures equal to or greater than about $100^{\circ} \mathrm{C}$ (Ellis and Mahon, 1977). For a more complete discussion of stable-isotope geochemistry, refer to Gat (1971) or Ellis and Mahon (1977).

Water samples for analyses of ${ }^{18} \mathrm{O}$ and $\mathrm{D}$ were collected from four wells and nine springs in and adjacent

TABLE 4.-Stable-isotope analyses of water from selected wells and springs

\begin{tabular}{|c|c|c|c|c|c|}
\hline $\begin{array}{l}\text { Well or spring } \\
\text { number }\end{array}$ & $1{ }^{\circ} \mathrm{C}$ & $\varepsilon \mathrm{D}_{\text {SMOW }}$ & $S^{18} \mathrm{O}_{\text {SMOW }}$ & $\Delta^{18} 0$ & $\begin{array}{l}\text { Reference } \\
\text { symbo) } \\
\text { (fig. 4) }\end{array}$ \\
\hline \multicolumn{6}{|c|}{ NONTHERMAL } \\
\hline $461 \mathrm{~N}-60 \mathrm{E}-13 \mathrm{ACClS}$ & 4.0 & -127 & -16.7 & +0.43 & a \\
\hline 45 iN-55E-25DAAIS & 6.5 & -128 & -16.6 & +.65 & $\mathrm{~b}$ \\
\hline $9 \mathrm{~S}-2 \mathrm{~W}-26 \mathrm{Cccls} \mathrm{S}^{1}$ & 7.0 & -122 & -16.5 & 0 & c \\
\hline $11 \mathrm{~S}-5 \mathrm{~W}-2 \mathrm{DAB} 1 \mathrm{~S}$ & 7.5 & -118 & -15.4 & +.60 & d \\
\hline $8 S-1 E-20 C A A 1 S^{2}$ & 9.5 & -128 & -17.1 & +.16 & e \\
\hline $13 S-4 E-12 C D D 1^{1}$ & 8.0 & -116 & -13.8 & +1.98 & $\mathrm{f}$ \\
\hline $14 S-14 E-11 \mathrm{CAB} 1 \mathrm{~S}$ & 12.0 & $\begin{array}{l}-126 \\
\text { THERMAI }\end{array}$ & -17.1 & 0 & $g$ \\
\hline $1 N-3 W-21 \mathrm{ACD} 1 \mathrm{~S}$ & 56.0 & -139 & -16.8 & +1.82 & $\mathrm{~h}$ \\
\hline $2 S-2 W-35 \mathrm{ACB} I$ & 40.0 & -145 & -17.8 & +1.58 & i \\
\hline $4 S-1 E-26 A B C 1^{2}$ & 27.0 & -144 & -18.2 & +1.05 & j \\
\hline $4 S-1 E-34 \mathrm{~B}_{A} A D 1^{2}$ & 76.0 & -145 & -17.5 & +1.88 & k \\
\hline $5 S-3 \mathrm{E}-26 \mathrm{BCB} 1^{2}$ & 83.0 & -146 & -17.5 & +2.00 & 1 \\
\hline $7 S-5 E-7 A B B 1^{2}$ & 39.0 & -135 & -17.6 & +.55 & $\mathrm{~m}$ \\
\hline $7 \mathrm{~S}-6 \mathrm{E}-9 \mathrm{BADl} 1^{2}$ & 50.5 & -142 & -18.2 & +.80 & $\mathrm{n}$ \\
\hline $8 S-14 E-30 A C D 1 S$ & 70.5 & -137 & -17.2 & +1.18 & $\circ$ \\
\hline $9 S-13 E-33 C B D 1$ & 30.0 & -131 & -16.2 & +1.42 & $\mathrm{p}$ \\
\hline $12 S-7 E-33 C B C I S$ & 71.5 & -130 & -16.6 & +.90 & q \\
\hline $14 S-9 E-2 B A A L^{1}$ & 26.5 & -124 & -16.4 & +.42 & r \\
\hline $16 \mathrm{~S}-9 \mathrm{E}-24 \mathrm{BB} 1 \mathrm{~S}$ & 54.5 & -131 & -17.3 & +.32 & $\mathrm{~s}$ \\
\hline
\end{tabular}

${ }^{1}$ Crosthwaite, unpublished data (1977).

${ }^{2}$ Rightmire, Young, and Whitehead (1976). to the study area. Additional stable-isotope analyses are available for the Bruneau-Grand View area (Rightmire, Young, and Whitehead, 1976; and Crosthwaite, unpubl. data, 1977). All the recent (1979) and selected older data from the Bruneau-Grand View area are shown in table 4.

A plot of stable-isotope data in standard $\delta$ values $(\% \circ)$ relative to SMOW, for the above data is shown in figure 4. Cold waters, indicated by closed circles in figure 4 , range in temperature from $4^{\circ}$ to $12^{\circ} \mathrm{C}$ and probably represent local, present-day meteoric water. Tritium analyses of the cold waters indicate all are relatively young (less than 20 years old). Several of the cold-water samples plot off the meteoric water line and probably indicate evaporation prior to being recharged.

Waters $\mathrm{k}$ and $\mathrm{I}$ in figure 4 , having temperatures near $80^{\circ} \mathrm{C}$ at the surface, were sampled from wells in the Oreana and Grand View areas. On the basis of the silica and $\mathrm{Na}-\mathrm{K}-\mathrm{Ca}$ geothermometer results, these waters have not attained temperatures much higher than those measured at the surface and probably represent unmixed hot water from the deep system. Waters that plot between the hot and cold waters in figure 4 range in temperature from $72^{\circ}$ to $27^{\circ} \mathrm{C}$ and are probably mixtures of the two waters.

The unmixed hot waters lack the conventional "oxygen shift" or enrichment of ${ }^{18} \mathrm{O}$ common to many geothermal systems (Ellis and Mahon, 1977). Instead, hot waters sampled from southwestern Idaho and northcentral Nevada exhibit a general depletion trend in both ${ }^{18} \mathrm{O}$ and $\mathrm{D}$ relative to the local cold meteoric waters. Some discussion of this phenomenon is warranted at this point.

Constraints to be applied to any interpretation of the isotopic composition of the waters shown in figure 4 require that the hot water, due to a depletion of about -17 and $-2 \%, \mathrm{D}$ and ${ }^{18} \mathrm{O}$, respectively, relative to the present-day cold waters, might have originated at a higher altitude or might have occurred as precipitation in the past when the regional climate was colder. Comparison of concentrations of stable isotopes with mean annual temperatures at springs in the Appalachian Mountains (Hobba and others, 1979) indicate a depletion rate for $\mathrm{D}$ of about $-4 \%$ per ${ }^{\circ} \mathrm{C}$, which is within the range of -3.2 to $-5.6 \%$ per ${ }^{\circ} \mathrm{C}$ suggested by Dansgaard (1964). On the basis of these estimates of D depletion with temperature and the normal temperature lapse rate of about $2^{\circ} \mathrm{C}$ per $1,000 \mathrm{ft}$, meteoric water having a $\mathrm{D}$ concentration comparable to that of the hot waters could occur if climatic conditions were about $3^{\circ}$ to $5^{\circ} \mathrm{C}$ cooler than at present or if precipitation fell at altitudes $1,500-2,700 \mathrm{ft}$ higher than the cold springs sampled during this study.

Rightmire, Young, and Whitehead (1976) suggested 
that recharge to the hot-water system in the Bruneau-Grand View area might have originated from areas of high altitude to the south in the Bruneau River drainage, or might have occurred during a time when the regional climate was much colder. Other processes during circulation that could produce waters depleted in ${ }^{18} \mathrm{O}$ and $\mathrm{D}$ are boiling and separation of steam; mixing of an older, hotter water with younger, cooler, local water; or isotope-exchange reactions between clay minerals and water. Neither of the first two processes lends itself to the conceptual model proposed for the system. Because it was previously suggested that hot waters in the Oreana and Grand View areas are not mixed and probably have not attained temperatures much in excess of $90^{\circ}-100^{\circ} \mathrm{C}$, any interpretation involving separation of steam or mixing of older, hotter water seems unwarranted.

The possibility that the stable-isotope composition of the hot waters has been altered due to hydrogen and oxygen isotope-exchange reactions with clays also is dismissed. Such waters probably would contain concentrations of dissolved solids in excess of those observed due to dissolution of the clay minerals, and their composition of stable isotopes would be enriched relative to SMOW.

Stable-isotope analyses of cold-water samples $a$ and $b$ (fig. 4) were collected in 1979 from springs near the head of the Bruneau River drainage at altitudes near 8,300 and 7,000 ft, respectively. Enrichment of stable isotopes in the cold springs relative to the hot water and the absence of nearby higher topography that could yield precipitation lighter in isotopic composition, indicates that none of the hot water discharged from the geothermal system is derived from present-day, local precipitation.

Considering the previous statement, the most probable explanation for the isotopic composition of the hot waters is recharge from precipitation that fell some time in the past when ambient temperatures were $3^{\circ}-5^{\circ} \mathrm{C}$ colder than at present. To obtain sufficient recharge depleted in the stable isotopes, colder climatic conditions must have persisted over long periods of time, rather than a few tens of years, and are probably correlative with one of the major ice advances.

While working in the St. Elias Mountains in southern Yukon Territory and Alaska, Denton and Karlen (1973) identified two major intervals of worldwide Holocene glaciation that occurred 200-350 years (Little Ice Age) and 2,400-3,300 years ago. During these episodes, they suggested that average temperatures were about $3.5^{\circ} \mathrm{C}$ colder than at present. A third, post-Wisconsin advance occurred 4,900-5,800 years ago but was less intense than the younger intervals. Prior to the 4,900- to 5,800-year interval, glacial advances were associated with late Wisconsin Glaciation in North America and occurred at about 2,500-year intervals beginning about 7,800 years BP (before present) (Denton and Karlen, 1973).
The 2,400- to 3,300-year dates suggested by Denton and Karlen (1973) are significantly close to the 2,000- to 3,500-year age given for post-hypsithermal glacier advances at Mount Rainier, Wash., given by Crandell and Miller (1964), and for the La Sal Mountains of eastern Utah, given by Richmond (1962); these ages may bracket the time during which precipitation and recharge to the geothermal system occurred. Occurrence of a colder climate about 3,000 years ago is within the time frame suggested by estimates of residence time in the geothermal system; however, this does not preclude the possibility of precipitation and recharge nearly 8,000 years $\mathrm{BP}$, or even earlier, during the Wisconsin Glaciation.

Considering the available data, meteoric water was probably recharged to the geothermal system when ambient temperatures were about $3.5^{\circ} \mathrm{C}$ colder than at present. The water could then circulate to some depth, be heated to temperatures near $100^{\circ} \mathrm{C}$, and become enriched in ${ }^{18} \mathrm{O}$ through water-rock reaction to ultimately resemble, isotopically, the unmixed hot waters shown in figure 4 .

\section{THERMAL GROUND-WATER OCCURRENCE AND MOVEMENT}

Thermal ground water occurs principally in discontinuous, or at least, compartmented zones created by the complex pattern of faulting in the area. Between Grand View and Oreana, thermal water occurs generally below about 2,000 ft in the Banbury Basalt and Idavada Volcanics. This area is approximately coincident with the resistivity low delineated on the apparent-resistivity maps and skin-depth pseudosections drawn by Hoover and Tippens (1975) from audio-magnetotelluric data. Two wells that penetrate to about $2,900 \mathrm{ft}$ in the Idavada Volcanics yield water having temperatures up to $81^{\circ} \mathrm{C}$ at discharge rates near $2,000 \mathrm{gal} / \mathrm{min}$. Wells in this vicinity completed below about 2,000 ft in the Banbury Basalt yield water generally greater than about $65^{\circ} \mathrm{C}$. Also, between Grand View and Oreana, and throughout the rest of the study area, thermal water occurs in one or more shallow aquifers; wells between about 250 and $1,900 \mathrm{ft}$, completed in sedimentary rocks of the Idaho Group, yield water between about $20^{\circ}$ and $30^{\circ} \mathrm{C}$ at a discharge rate between about 5 and $1,000 \mathrm{gal} / \mathrm{min}$. Artesian head in the deep aquifer is generally several hundred feet above the artesian head in the shallow aquifer(s), and some upward movement of water between the two aquifers probably occurs (Young and Whitehead, 1975).

Depths of wells, water levels, and water temperatures are highly variable in the volcanic rocks. Water levels in these rocks range from several hundred feet above land surface (as artesian heads) to nearly $900 \mathrm{ft}$ below land surface. Generally, artesian heads are above land surface in wells in the northern part of the study area adjacent to 
TABLE 5.-Record of wells

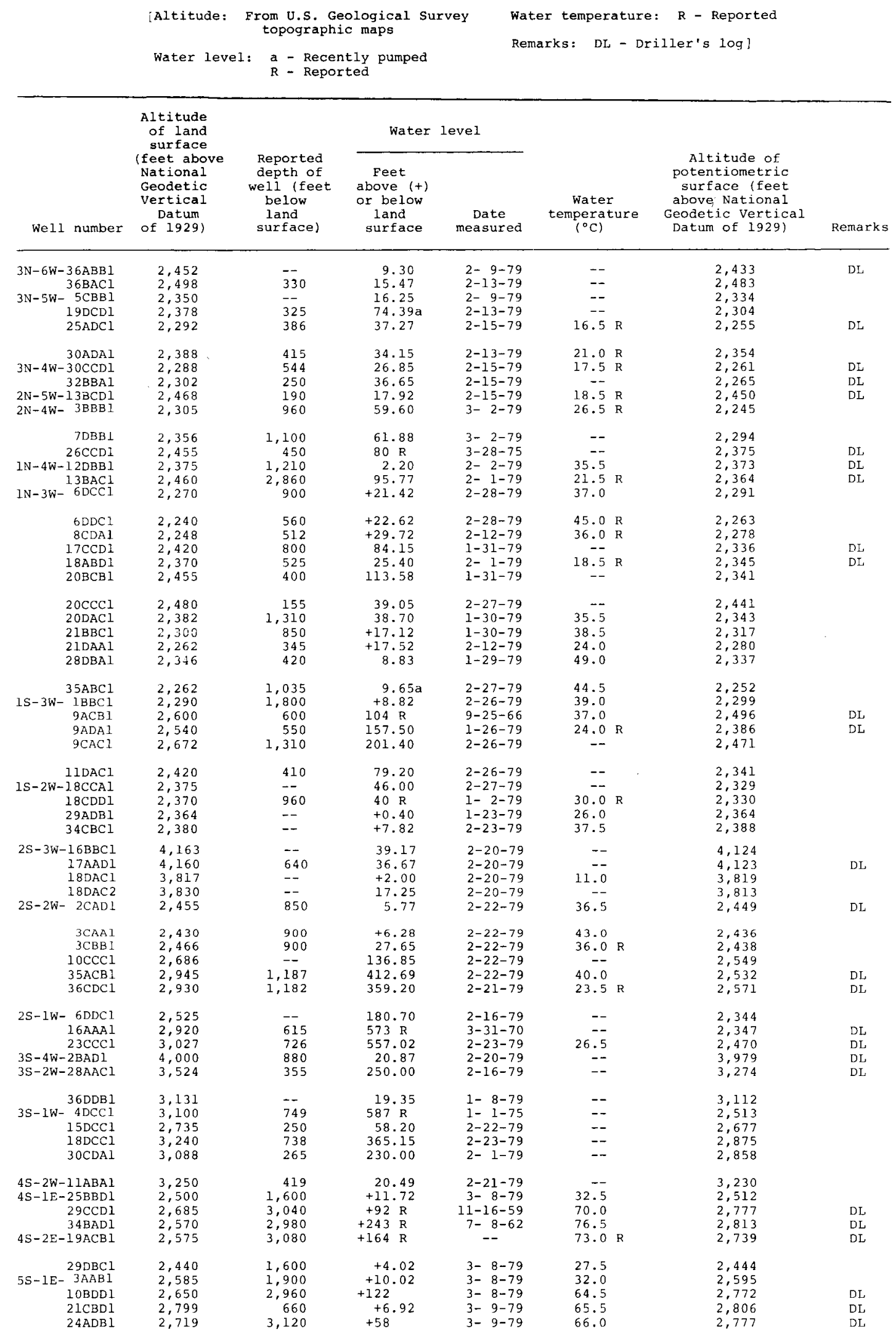


TABLE 5.-Record of wells-Continued

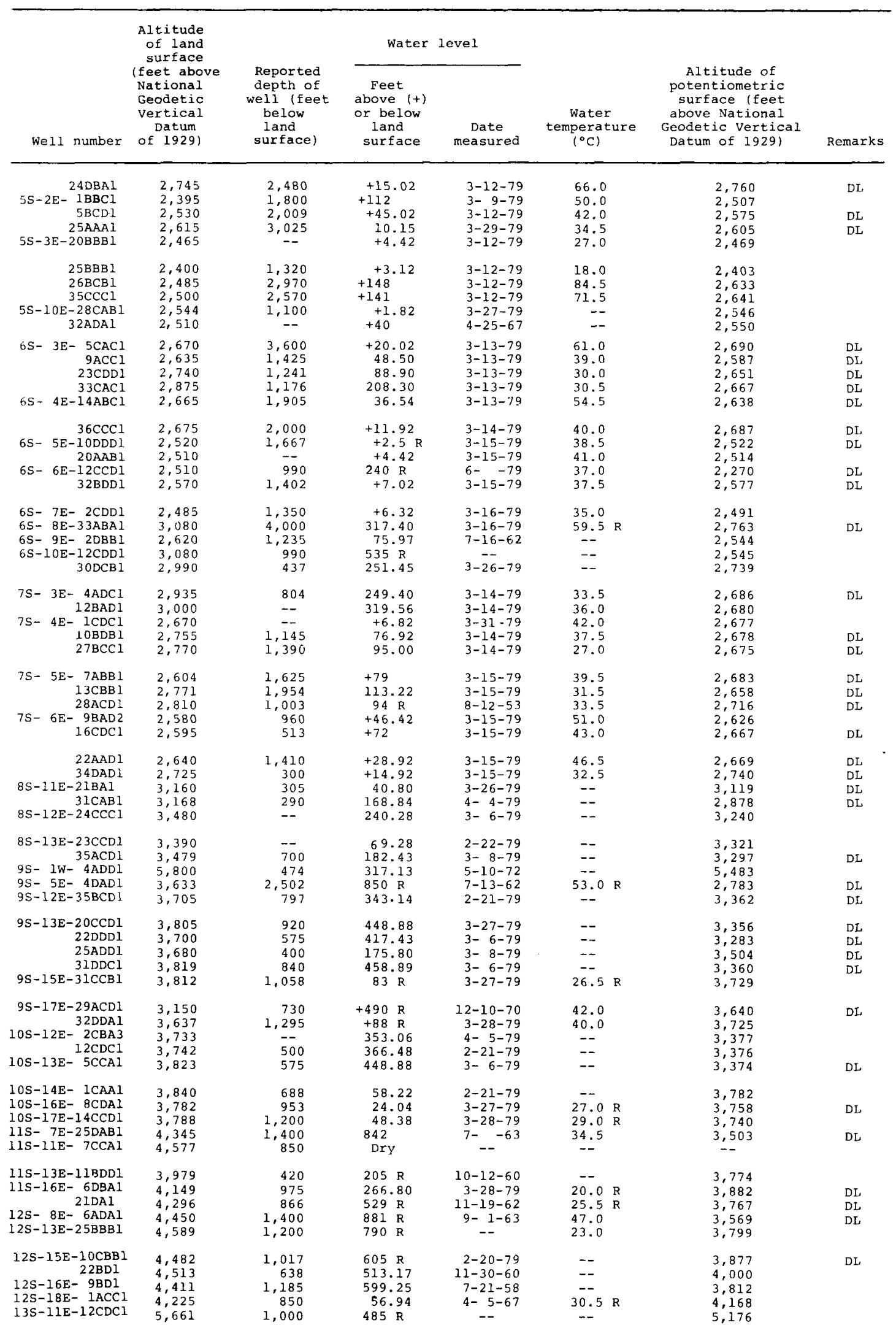


TABLE 5.-Record of wells-Continued

\begin{tabular}{|c|c|c|c|c|c|c|c|}
\hline Well number & $\begin{array}{l}\text { Altitude } \\
\text { of land } \\
\text { surface } \\
\text { (feet above } \\
\text { National } \\
\text { Geodetic } \\
\text { Vertical } \\
\text { Datum } \\
\text { of } 1929 \text { ) }\end{array}$ & $\begin{array}{l}\text { Reported } \\
\text { depth of } \\
\text { well (feet } \\
\text { below } \\
\text { land } \\
\text { surface) }\end{array}$ & $\begin{array}{l}\text { Water } \\
\text { Feet } \\
\text { above (t) } \\
\text { or below } \\
\text { land } \\
\text { surface }\end{array}$ & $\begin{array}{c}\text { Date } \\
\text { measured }\end{array}$ & $\begin{array}{c}\text { water } \\
\text { temperature } \\
\left({ }^{\circ} \mathrm{C}\right)\end{array}$ & $\begin{array}{c}\text { Altitude of } \\
\text { potentiometric } \\
\text { surface (feet } \\
\text { above National } \\
\text { Geodetic Vertical } \\
\text { Datum of 1929) }\end{array}$ & Remarks \\
\hline $\begin{array}{r}26 \mathrm{BBB} 1 \\
13 \mathrm{~S}-12 \mathrm{E}-31 \mathrm{BDA} 1 \\
36 \mathrm{ABD} 1 \\
13 \mathrm{~S}-14 \mathrm{E}-35 \mathrm{CDD} 1 \\
13 \mathrm{~S}-16 \mathrm{E}-12 \mathrm{DAA} 1\end{array}$ & $\begin{array}{l}5,259 \\
5,366 \\
5,245 \\
5,120 \\
4,742\end{array}$ & $\begin{array}{r}1,050 \\
600 \\
620 \\
518 \\
700\end{array}$ & $\begin{array}{ll}600 & \mathrm{R} \\
340 & \mathrm{R} \\
575 & \mathrm{R} \\
232.67 \\
122.94\end{array}$ & $\begin{array}{c}-- \\
-- \\
8-\overline{18-59} \\
3-28-79\end{array}$ & $\begin{array}{l}20.0 \\
21.5 \\
-- \\
\overline{--} \\
36.5 \mathrm{R}\end{array}$ & $\begin{array}{l}4,659 \\
5,026 \\
4,670 \\
4,887 \\
4,619\end{array}$ & DL \\
\hline $\begin{array}{r}14 \mathrm{~S}-9 \mathrm{E}-2 \mathrm{BAAl} \\
14 \mathrm{~S}-12 \mathrm{E}-12 \mathrm{ACCl} \\
15 \mathrm{BCCl} \\
14 \mathrm{~S}-15 \mathrm{E}-2 \mathrm{BBAD} 2 \\
15 \mathrm{~S}-6 \mathrm{E}-10 \mathrm{BBA1}\end{array}$ & $\begin{array}{l}5,250 \\
5,516 \\
5,518 \\
4,979 \\
5,104\end{array}$ & $\begin{array}{l}953 \\
850 \\
810 \\
455 \\
850\end{array}$ & $\begin{array}{ll}623 & \mathrm{R} \\
540 & \mathrm{R} \\
395 & \mathrm{R} \\
111.65 \\
727 & \mathrm{R}\end{array}$ & $\begin{array}{c}7-16-56 \\
-- \\
-\overline{-} \\
3-20-79 \\
--\end{array}$ & $\begin{array}{l}26.5 \mathrm{R} \\
-- \\
-- \\
19.5 \mathrm{R} \\
--\end{array}$ & $\begin{array}{l}4,627 \\
4,976 \\
5,123 \\
4,867 \\
4,377\end{array}$ & $\begin{array}{l}\mathrm{DL} \\
\mathrm{DL}\end{array}$ \\
\hline $\begin{array}{l}15 S-9 E-34 \mathrm{BBCl} \\
15 \mathrm{~S}-11 \mathrm{E}-30 \mathrm{BAAl} \\
15 \mathrm{~S}-14 \mathrm{E}-2 \mathrm{ACD}\end{array}$ & $\begin{array}{l}5,595 \\
5,378 \\
5,273\end{array}$ & $\begin{array}{l}850 \\
550 \\
815\end{array}$ & $\begin{array}{ll}705 & R \\
500 & R \\
145.27\end{array}$ & $4-\overline{-}$ & $\begin{array}{l}-- \\
-- \\
--\end{array}$ & $\begin{array}{l}4,890 \\
4,878 \\
5,128\end{array}$ & DL \\
\hline
\end{tabular}

the Snake River. The artesian head is generally below land surface to the south, where drillers report that when water is encountered, the water level in the wells rises several feet to several tens of feet.

A generalized potentiometric surface for the deep hydrothermal system, based on measured or reported water levels in 148 wells, is shown in figure 2. Water levels used to define this surface are from wells completed in volcanic rocks and from the deepest wells in the area. The measured or reported water levels are given in table 5. An attempt was made to convert water levels to a cold-water equivalent head; however, insufficient data to do this for many wells resulted in a loss of data points. Therefore, the potentiometric surface shown in figure 2 is not temperature corrected.

The general direction of regional ground-water movement can be inferred from the potentiometric-surface map (fig. 2). Movement is down the hydraulic gradient and roughly perpendicular to the potentiometric contours, from areas of recharge to areas of discharge.

\section{TEMPERATURE DISTRIBUTION AND HEAT FLOW}

The widespread occurrence of thermal ground water in southwestern Idaho and north-central Nevada suggests a broad heat source. Heat-flow distribution on the Snake River Plain is interpreted by Brott, Blackwell, and Mitchell (1978) to be related to combined effects of crustal thermal refraction and a large crustal heat source emplaced under the western part of the plain 10-15 million years ago. Any discussion of the geothermal system, therefore, must consider deep circulation of meteoric water in an area of above-normal heat flow.
Heat-flow values reported by Brott, Blackwell, and Mitchell (1978) ranged from 3.3 HFU (heat-flow unit; 1 HFU equals 1 microcalorie per centimeter squared per second) in granitic rocks near the margin of the western Snake River Plain to 1.5 HFU near the Snake River. Sass and others (1971) reported heat flow in north-central Nevada to be 3.3 HFU. McIntyre (1979) calculated a heat flow of $1.7 \mathrm{HFU}$, using average thermalconductivity values of Brott, Blackwell, and Mitchell (1978) and a bottom-hole temperature of $150^{\circ} \mathrm{C}$ in an 11,125 -ft test hole. Subsequently, a series of bottom-hole temperature measurements were made at intervals of time and extrapolated to infinity in the manner described by Parasnis (1971) to obtain a bottom-hole temperature of $196^{\circ} \mathrm{C}$ and a corresponding thermal gradient of $1.7^{\circ} \mathrm{C}$ per $100 \mathrm{ft}$. This thermal gradient is less than the $2.0^{\circ} \mathrm{C}$ per $100 \mathrm{ft}$ estimated by Young and Whitehead (1975) and is greater than the $1.4^{\circ} \mathrm{C}$ per $100 \mathrm{ft}$ estimated by McIntyre (1979), due to use in the computation of a greater depth $(11,125 \mathrm{ft})$ and higher bottom-hole temperature $\left(196^{\circ} \mathrm{C}\right)$, respectively.

Using a thermal gradient of $1.7^{\circ} \mathrm{C}$ per $100 \mathrm{ft}$ and the thermal-conductivity value used by McIntyre, a heat flow of $2.2 \mathrm{HFU}$ was obtained, which is within the 1.5-3.3 HFU range reported by Brott, Blackwell, and Mitchell (1978) for the Snake River Plain.

If a heat flow of $2.2 \mathrm{HFU}$ over the entire $1,520 \mathrm{mi}^{2}$ of the system is assumed (see following section on "Conceptual Model of the System", a net heat flux into the system of $8.7 \times 10^{7} \mathrm{cal} / \mathrm{s}$ is indicated. Heat is discharged naturally from the system conductively at the surface, convectively in thermal-spring discharge, and advectively in thermal ground water moving northward out of the area. Conductive and convective discharge can 
be estimated and the advective discharge determined from the relation:

$$
Q_{\text {advective }}=Q_{\text {input }}-Q_{\text {conductive }}-Q_{\text {convective }} \text {. }
$$

Heat discharged conductively at the surface was estimated using temperature data in Young and Whitehead (1975) from wells less than about $2,000 \mathrm{ft}$ deep completed in sedimentary deposits. Average thermal gradient in six wells was $0.9^{\circ} \mathrm{C}$ per $100 \mathrm{ft}$. Thermal conductivity measured in 15 core samples of sand and clay was $3.6 \times 10^{-3}\left[\mathrm{cal} /\left(\mathrm{cm} \mathrm{s} \cdot{ }^{\circ} \mathrm{C}\right)\right]$ (Brott and others, 1978 , p. 28). Using these values, a conductive heat flow of $1.1 \mathrm{HFU}$ is obtained, or about $4.3 \times 10^{7} \mathrm{cal} / \mathrm{s}$ for the $1,520 \mathrm{mi}^{2}$ system.

Convective heat flow discharged naturally in thermal springs was $1.6 \times 10^{7} \mathrm{cal} / \mathrm{s}$ on the basis of temperature and discharge measurements from springs included in Stearns, Stearns, and Waring (1937). Using the above equation, the amount of heat discharged advectively in thermal ground water leaving the system is $\left(8.7 \times 10^{7}\right)-\left(4.3 \times 10^{7}\right)-\left(1.6 \times 10^{7}\right)$, or $2.8 \times 10^{7} \mathrm{cal} / \mathrm{s}$.

On the basis of the conceptual model proposed, heat is discharged advectively from the system in water moving across the northern boundary, which is nearly coincident with the course of the Snake River. If the temperature of the water is known, the volume of discharge, $Q$, necessary to transport $2.8 \times 10^{7} \mathrm{cal} / \mathrm{s}$ from the system can be calculated from the relation,

$$
Q=\frac{\text { Net heat flux }}{\text { Heat content of the water }} .
$$

Using the heat content of the thermal water, the volume of discharge across the boundary necessary to transport the residual heat from the system is estimated for various water temperatures as shown in table 6 .

TABLE 6. -Estimated thermal-water discharge, on the basis of enthalpy

\begin{tabular}{ccc}
\hline $\begin{array}{c}\text { Temperature of } \\
\text { thermal water } \\
\left({ }^{\circ} \mathrm{C}\right)\end{array}$ & \multicolumn{2}{c}{ Discharge, $Q$} \\
\cline { 2 - 3 }$(\mathrm{ft} / \mathrm{s})$ & $($ acre-ft/yr) \\
\hline 90 & 12.8 & 9,300 \\
70 & 14.5 & 10,500 \\
60 & 16.8 & 12,200 \\
50 & 20.1 & 14,600 \\
40 & 25.0 & 18,100 \\
\hline
\end{tabular}

Thermal-water temperatures along the northern boundary range from $35^{\circ}$ to $81^{\circ} \mathrm{C}$ and average about $50^{\circ} \mathrm{C}$. If an average temperature of about $50^{\circ} \mathrm{C}$ is assumed for the thermal water all along the northern boundary, from table 6 , about $25 \mathrm{ft}^{3} / \mathrm{s}$, or nearly $18,000 \mathrm{acre}-\mathrm{ft} / \mathrm{yr}$, is required to transport convectively, $2.8 \times 10^{7} \mathrm{cal} / \mathrm{s}$ of heat from the system.

Using an estimate of recharge (thermal-water outflow across the northern boundary, plus hot-spring discharge) and the volume of the geothermal reservoir, the residence time of water in the system can be calculated. From the equation (Pearson and Truesdell, 1978) for calculating tritium content $(\mathrm{T})$ at any point in a wellmixed reservoir for some transit time $(t)$,

$$
\frac{\mathrm{dT}}{\mathrm{d} t}=\mathrm{T}_{0} \frac{Q}{V}-\mathrm{T} \frac{Q}{V}-\gamma t,
$$

where $\mathrm{T}_{0}, Q, V, \gamma t$ are tritium concentration in recharge water, input (= output), reservoir pore volume and decay constant (ln 2/half-life), respectively, the ratio $\mathrm{V} / \mathrm{Q}$ is the turnover time for the system. Bolin and Rodhe (1972) have shown that this turnover time is identical to the average transit time or average age of particles leaving the reservoir, which they prefer to term "residence time."

Applying the relation $t=V / Q$ to the southwestern Idaho north-central Nevada geothermal system, and using the values for reservoir volume and recharge of 576 $\mathrm{mi}^{3}$ and $39.8 \mathrm{ft}^{3} / \mathrm{s}$, respectively $\left(25.0 \mathrm{ft}^{3} / \mathrm{s}\right.$ ground-water outflow to the north, plus $14.8 \mathrm{ft}^{3} / \mathrm{s}$ hot-spring discharge), residence time is about 3,400 years for a reservoir having an effective porosity of 0.05 ; residence time is about 6,800 years for a reservoir having an effective porosity of 0.10 . Brott, Blackwell, and Mitchell (1978) obtained porosities of 0.05 from laboratory analyses of core samples from silicic volcanic rock. This is probably a minimum for the reservoir, considering the secondary porosity that likely occurs due to faulting.

Calculations for the geothermal system apply to an average reservoir thickness of $2,000 \mathrm{ft}$. If the geothermal reservoir volume is less than $576 \mathrm{mi}^{3}$, or if the recharge is greater than $39.8 \mathrm{ft}^{3} / \mathrm{s}$, calculated residence time is reduced; if the reservoir volume is greater or if the discharge is less, calculated residence time is greater.

In spring 1982, water samples were obtained from several of the hottest wells by the authors and W. H. Low (U.S. Geological Survey) for analysis of carbon isotopes ${ }^{12} \mathrm{C},{ }^{13} \mathrm{C}$, and ${ }^{14} \mathrm{C}$. On the basis of analysis of stable-isotope data discussed earlier, water from these wells has not mixed with shallower, local ground water and probably is representative of hot water from the deep system. Although ${ }^{13} \mathrm{C}$ to ${ }^{12} \mathrm{C}$ ratios obtained from carbon-isotope analysis of water from upland cold 
springs are not presently available, preliminary estimates on the basis of carbon-14 determinations indicate the geothermal waters in the area have an apparent age in the range of $18,000-25,000$ years (oral commun., W. H. Low, 1982).

Reservoir thermal energy in the Bruneau-Grand View system was estimated by Brook and others (1979) using the relation:

$$
q_{r}=\rho c(a)(d)\left(t-t_{r e f}\right)
$$

where

$q_{r}=$ reservoir thermal energy,

$\rho c=$ volumetric specific heat of rock plus water,

$a=$ reservoir area,

$d=$ reservoir thickness,

$t=$ reservoir temperature, and

$t_{\text {ref }}=$ reference temperature.

From this equation, and using the conceptual model described in the following section, the reservoir thermal energy for the geothermal system in southwestern Idaho and north-central Nevada is about $130 \times 10^{18}$ cal. This differs from the value of $107 \times 10^{18} \mathrm{cal}$ obtained by Brook and others (1979), due to the larger reservoir volume assumed.

\section{CONCEPTUAL MODEL OF THE SYSTEM}

The conceptual model is based on available geologic, geophysical, and hydrologic data. It is, of necessity, generalized and probably an oversimplification of what is undoubtedly a complex system. This model is not unique but can be considered a first approximation, established within existing constraints. As additional data are generated, more specific models will be developed.

An interpretation by Mabey (1976) of seismic, magnetic, and gravity data indicates about $3,280 \mathrm{ft}$ of interbedded basalt and sedimentary rocks of Pliocene to Holocene age overlie about $1,800 \mathrm{ft}$ of silicic volcanic rocks of Miocene and Pliocene age. Older basalts of Tertiary age and rocks of the upper and lower crust underlie the silicic volcanic rocks. McIntyre (1979) examined well cuttings from the Anschutz Federal No. 1 drill hole located in $\mathrm{NE}^{1 / 4} \mathrm{SW}^{1 / 4}$ sec. 13 , T. 5 S., R. 1 E., and described a 2,000-ft section of rhyolite between 2,720 and $4,750 \mathrm{ft}$. Drillers' logs for wells in the area indicate that hot water is encountered in rhyolite at a depth of about $2,900 \mathrm{ft}$. On the basis of this evidence, the rhyolite is considered to be the principal reservoir rock in the northern part of the study area.

For simplicity, a single aquifer about $2,000 \mathrm{ft}$ thick, at a depth of 3,000 to $5,000 \mathrm{ft}$, is proposed to be in the silicic volcanic rocks of the Idavada Volcanics. Considering the following three items, that the southern boundary of the system is the edge of the Snake River Plain-approximated using the aeromagnetic map of Zietz, Gilbert, and Kirby (1978) - that the northern boundary is coincident with the course of the Snake River, and that the east-west boundaries are as shown on plate 1 , then, the surface area of the hot-water reservoir is about $1,520 \mathrm{mi}^{2}$, and the volume of rock is $576 \mathrm{mi}^{3}$. There is no evidence to indicate the existence of a shallow, local heat source. Available data indicate only slightly above-normal heat flow over most of the Snake River Plain. In the western part of the plain, however, heat-flow values range from about 1.5 HFU to $3.3 \mathrm{HFU}$ along the southern margin (Brott and others, 1978). This model differs from previously described geothermal convection models where meteoric water is circulated to depths near 10,000 $\mathrm{ft}$, is heated, and then, due to density difference between the hot and cold water, rises along faults to ultimately fill the available pore space in some reservoir rock. The proposed model suggests that for this part of the Snake River Plain having a heat-flow value of about $1.7 \mathrm{HFU}$, water temperatures equivalent to those estimated using geothermometers can be attained at depths near the base of the geothermal reservoir at about $5,000 \mathrm{ft}$ in rocks of the Idavada Volcanics, and deeper circulation of water below that depth is not required. Considerable transfer of heat convectively within the reservoir is implied, however, by the occurrence of $80^{\circ} \mathrm{C}$ water in two wells at a depth of about $2,900 \mathrm{ft}$. In a solely conductive regime, and on the basis of data from the deep drill hole, water temperatures of $80^{\circ} \mathrm{C}$ would occur at a depth of about $5,000 \mathrm{ft}$. For water temperatures of $80^{\circ} \mathrm{C}$ to occur at a depth of only $2,900 \mathrm{ft}$, a heat flow near $3.2 \mathrm{HFU}$ would be required; such a high heat flow would result in a bottomhole temperature of about $270^{\circ} \mathrm{C}$ in the deep drill hole. Neither of these is consistent with a conceptual model of the geothermal system developed based on available data.

On the basis of thermal considerations, recharge to the system is about $40 \mathrm{ft}^{3} / \mathrm{s}$. Using the stable-isotope data, it is not possible to suggest a principal recharge area for the convective system. However, the generalized potentiometric contours (pl. 2) indicate that the recharge area lies somewhere to the south and may be considerably removed from the area of discharge. Water in the thermal system is meteoric in origin and most likely fell as rain or snow in the distant past when the regional climate was much colder than at present. Water is heated by circulation to depths near $5,000 \mathrm{ft}$. Lack of significant amounts of tritium in the water indicates minimum residence time in the system is more than 30 years. On the basis of estimates of reservoir volume and amount of recharge, the residence time in the system is probably at least $3,400-6,800$ years, and in view of recent preliminary carbon-14 analyses, perhaps as long as 25,000 years. 
The dilute nature of the hot water (less than about 400 $\mathrm{mg} / \mathrm{L}$ dissolved solids) in the system could indicate one of three possibilities: (1) rapid water movement and short residence time, hence, little water-rock reaction; (2) reservoir temperature sufficiently low so that waterrock reaction occurs very slowly; or (3) a very old system, in which most of the minerals in the rock have been leached, owing to long contact with circulating hot water. None of the above reasons are sufficient by themselves to adequately explain the dilute nature of the thermal water. Interpretation of the tritium and stable-isotope data and of the subsurface temperatures calculated using chemical geothermometers precludes using either possibility 1 or 2 above as the basis for a conceptual model of the geothermal system. Concentrations of fluoride, lithium, and boron in the thermal water indicate that relatively soluble minerals still persist in the reservoir rock and are still being dissolved. If possibility 3 were true, the more soluble minerals already would have been dissolved and concentrations of fluoride, lithium, and boron in the thermal water would be much less.

Preliminary interpretation of carbon-14 analyses of the thermal water has extended the estimates of residence time in the system. Consideration of a longer residence time will alter the conceptual model proposed. With increased time constraints, in order to address the thermal and hydraulic considerations, the new model must include (1) an increase in the size or effective porosity of the reservoir; (2) a reduction in the outflow, hence, total recharge to the system; (3) an increase in the temperature of the water that discharges from the system; or (4) some combination of the above.

In any case, the proposed generalized conceptual model is one of an old system with long residence time where circulation has occurred for thousands or tens of thousands of years. The volume of reservoir rock involved is sufficiently large so that soluble minerals continue to be dissolved, and the chemistry of the water reflects more the type of rock through which the water has passed than the residence time or the reservoir temperature.

\section{SUMMARY}

Rocks of igneous, sedimentary, and metamorphic origin in southwestern Idaho and north-central Nevada range in age from Precambrian to Holocene. Rocks related to the occurrence of thermal ground water include (1) sedimentary rocks of the Idaho Group of Quaternary and Tertiary age; (2) basalt of Quaternary and Tertiary age, which consists chiefly of the Banbury Basalt of Tertiary age; and (3) silicic volcanic rocks of Tertiary age, which include the Idavada Volcanics.
The silicic volcanic rocks and the Banbury Basalt are thought to be the chief reservoir rocks of the thermal ground-water system(s) in the study area. Low concentration of magnesium in the thermal water seems to favor silicic volcanic rocks as the principal reservoir rock. These rocks have been fractured and displaced by a system of northwest-trending faults, particularly in the area adjacent to the Snake River.

Thermal ground water generally occurs under artesian conditions; water temperatures range from $20^{\circ} \mathrm{C}$ to more than $80^{\circ} \mathrm{C}$. The artesian heads are variable and range from a few feet above the water-bearing zone to several hundred feet above land surface. Thermal ground water in the study area occurs, for the most part, in discontinuous, or at least, compartmented zones. Groundwater movement in the western part of the area is generally northeastward. Ground water in the eastern part of the area tends to move northward and northwestward.

Nonthermal ground waters are generally a calcium bicarbonate type and have dissolved-solids concentrations generally less than $120 \mathrm{mg} / \mathrm{L}$. The hot waters, which are thought to be representative of the deep convective system, are generally a sodium carbonate or bicarbonate type and have dissolved-solids concentrations generally less than about $400 \mathrm{mg} / \mathrm{L}$.

Estimated reservoir temperatures using the $\mathrm{Na}-\mathrm{K}-\mathrm{Ca}$ and $\mathrm{H}_{3} \mathrm{SiO}_{4}{ }^{-}$corrected silica geothermometers range from about $80^{\circ}$ to $96^{\circ} \mathrm{C}$ in southwestern Idaho and from about $51^{\circ}$ to $106^{\circ} \mathrm{C}$ in north-central Nevada. The sulfate water isotope geothermometer indicates maximum reservoir temperatures in southwestern Idaho are near $100^{\circ} \mathrm{C}$.

Tritium concentrations in the hot water in southwestern Idaho are near zero, which indicates a minimum residence time of 30 years. Tritium concentrations of cold springs in the southern part of the study area indicate residence times as short as 2 years or as long as 20 years. Stable isotopes are depleted in the hot waters relative to present-day meteoric waters and were probably recharged several thousand years ago during one of the Holocene glacial advances when ambient tempertures were about $3.5^{\circ} \mathrm{C}$ colder than at present. On the basis of estimated recharge rate and the pore volume of the geothermal reservoir, minimum residence time in the system may be $3,400-6,800$ years; on the basis of preliminary estimates of carbon-14 determinations, residence time could be as long as 25,000 years.

Widespread occurrence of thermal ground water in southwestern Idaho and north-central Nevada suggests a broad heat source. Reported heat-flow values range from 1.5 to 3.3 HFU. Extrapolation of data from a deep test hole in the northern part of the study area indicates a conductive heat flow of $2.2 \mathrm{HFU}$. A heat flow of $2.2 \mathrm{HFU}$ would be associated with a temperature gradient of $1.7^{\circ} \mathrm{C}$ per $100 \mathrm{ft}$. Reservoir temperatures of $80^{\circ}-96^{\circ} \mathrm{C}$ 
could be attained by circulation of water to depths between about 4,000 and $5,000 \mathrm{ft}$. Additional data from the test hole indicate a 2,000-ft section of rhyolite between 2,720 and $4,750 \mathrm{ft}$, which is considered to be the principal reservoir rock (Idavada Volcanics) in the northern part of the study area.

Using an average conductive heat flow of $2.2 \mathrm{HFU}$ for the study area, heat flux into the system is estimated to be $8.7 \times 10^{7} \mathrm{cal} / \mathrm{s}$. Considering heat losses of $4.3 \times 10^{7}$ and $2.8 \times 10^{7} \mathrm{cal} / \mathrm{s}$ to conduction and thermal-spring discharge, respectively, the net amount of heat that is transported convectively through the system is about $2.8 \times 10^{7} \mathrm{cal} / \mathrm{s}$. Assuming the heat is discharged advectively from the system in water moving across the northern boundary, about $25.0 \mathrm{ft}^{3} / \mathrm{s}$, or 18,000 acre- $\mathrm{ft} / \mathrm{yr}$, of $50^{\circ} \mathrm{C}$ water would be required to transport $2.8 \times 10^{7}$ $\mathrm{cal} / \mathrm{s}$ of heat from the system. The reservoir thermal energy for the geothermal system is about $130 \times 10^{18} \mathrm{cal}$.

The conceptual model proposed for southwestern Idaho is one of an old system, where water has circulated for thousands, even tens of thousands of years. The principal reservoir rock is in the Idavada Volcanics at depths between about 3,000 and $5,000 \mathrm{ft}$. Water in the system is meteoric in origin and fell as rain or snow in the distant past. Water is heated within the reservoir by circulation to depths near $5,000 \mathrm{ft}$. Residence times near 3,000 years are indicated on the basis of climatic evidence, as well as physical reservoir parameters; however, residence times of as long as 25,000 years are not precluded.

\section{SELECTED REFERENCES}

Benseman, R. F., 1959, Estimating the total heat output of natural thermal regions: Journal of Geophysical Research, v. 64, no. 8, p. 1057-1062.

Bolin, Bert, and Rodhe, Henning, 1972, A note on the concepts of age distribution and transit time in natural reservoirs: Tellus 25 (1973), v. 1, p. 58-62.

Bond, J. G., compiler, 1978, Geologic map of Idaho: Moscow, Idaho, Idaho Bureau of Mines and Geology, 1 sheet, 1:500,000.

Brook, C. A., and others, 1979, Hydrothermal convection systems with reservoir temperatures $\geq 90^{\circ} \mathrm{C}$, in Assessment of geothermal resources of the United States: U.S. Geological Survey Circular $790,163 \mathrm{p}$

Brott, C. A., Blackwell, D. D., and Mitchell, J. C., 1978, Tectonic implications of the heat flow of the western Snake River Plain, Idaho: Geological Society of American Bulletin, v. 89, p. 1697-1707.

Chapman, S. L., and Ralston, D. R., 1970, Ground-water resources of the Blue Gulch area in eastern Owyhee and western Twin Falls Counties, Idaho: Idaho Department of Water Administration, Water Information Bulletin no. 20, 36 p.

Craig, Harmon, 1963, The isotopic geochemistry of water and carbon in geothermal areas, E. Tongiori, ed., in Spolette Conference on Nuclear Geology and Geothermal Areas, Spolette, 1963: Rome, Consiglio Nazionale delle Recerche, $17 \mathrm{p}$.

Crandell, D. R., and Miller, R. D., 1964, Post-hypsithermal glacier advances at Mount Rainier, Washington: U.S. Geological Survey Professional Paper 501-D, p. 110-114.

Crosthwaite, E. G., 1977, Stable-isotope analyses: Unpublished data on file in Idaho District office, U.S. Geological Survey.
Dansgaard, W., 1964, Stable isotopes in precipitation: Tellus, v. 16, p. 436-468.

Denton, G. H., and Karlen, W., 1973, Holocene climatic variations - their pattern and possible cause: Quaternary Research, v. 3 , p. $155-205$.

Ekren, E. B., McIntyre, D. H., and Bennett, E. H., 1978, Preliminary geologic map of the west half of Owyhee County, Idaho: U.S. Geological Survey Open-File Report 78-341, 14 p.

Ellis, A. J., and Mahon, W. A. J., 1977, Chemistry and geothermal systems: New York, Academic Press, 392 p.

Fournier, R. O., 1979, Geochemical and hydrologic considerations and the use of enthalpy-chloride diagrams in the prediction of underground conditions in hot-spring systems: Journal of Volcanology and Geothermal Research, v. 5, pl. 16.

Fournier, R. O., and Potter, R. W., II, 1979, Magnesium correction to the Na-K-Ca chemical geothermometer: Geochimica et Cosmochimica Acta, v. 43, p. 1543-1550.

Fournier, R. O., and Rowe, J. J., 1966, Estimation of underground temperatures from the silica content of water from hot springs and wet steam wells: American Journal of Science, v. 264, p. 685-695.

Fournier, R. O., Sorey, M. L., Mariner, R. L., and Truesdell, A. H., 1979, Chemical and isotopic prediction of aquifer temperatures in the geothermal system at Long Valley, California: Journal of Volcanology and Geothermal Research, v. 5, p. 17-34.

Fournier, R. O., and Truesdell, A. H., 1973, An empirical Na-K-Ca geothermometer for natural waters: Geochimica et Cosmochimica Acta, v. 36., p. 1255-1275.

Gat, J. R., 1971, Comments on the stable isotope method in regional groundwater investigations: Water Resources Research, v. 7, no. 4, p. $980-993$.

Hobba, W. A., Jr., Fisher, D. W., Pearson, F. J., Jr., and Chemerys, J. C., 1979, Hydrology and geochemistry of thermal springs of the Appalachians: U.S. Geological Survey Professional Paper 1044-E, $36 \mathbf{p .}$

Hoover, D. B., and Tippens, C. L., 1975, A reconnaissance audiomagnetotelluric survey, Bruneau-Grand View area, Idaho, in $\mathrm{H}$. W. Young and R. L. Whitehead, Geothermal investigations in Idaho, Part 2, An evaluation of thermal water in the Bruneau-Grand View area, southwest Idaho: Idaho Department of Water Resources, Water Information Bulletin no. 30, 126 p.

Kharaka, Y. K., and Barnes, Ivan, 1973, SOLMNEQ: Solutionmineral equilibrium computations: U.S. Geological Survey Computer Contributions, PB 215-899, 82 p.

Mabey, D. R., 1976, Interpretation of a gravity profile across the western Snake River Plain, Idaho: Geology, v. 4, no. 1, p. 53-55.

McIntyre, D. H., 1979, Preliminary description of Anschutz Federal No. 1 drill hole, Owyhee County, Idaho: U.S. Geological Survey Open-File Report 79-651, 15 p.

McKenzie, W. F., and Truesdell, A. H., 1977, Geothermal reservoir temperatures estimated from the oxygen isotope compositions of dissolved sulfate and water from hot springs and shallow drill holes: Geothermics, v. 5, p. 51-61.

Nir, A., 1964, On the interpretation of tritium "age" measurements of groundwater: Journal of Geophysical Research, v. 69, no. 12, p. 2589-2595.

O'Neil, J. R., and Kharaka, Y. K., 1976, Hydrogen and oxygen isotope exchange reactions between clay minerals and water: Geochimica et Cosmochimica Acta,v. 40, p. 241-246.

Parasnis, D. S., 1971, Temperature extrapolation to infinite time in geothermal measurements: Geophysical Prospecting, v. 19, no. 4, p. 612-614.

Pearson, F. J., and Truesdell, A. H., 1978, Tritium in the waters of Yellowstone National Park, in Robert E. Zartman, ed., Short Papers of the Fourth International Conference, Geochronology, Cosmochronology, Isotope Geology 1978, Colorado, August 20-25, 1978: U.S. Geological Survey Open-File Report 78-701, p. 327-329. 
Renner, J. L., White, D. E., and Williams, D. L., 1975, Hydrothermal convection systems, in D. E. White and D. L. Williams, eds., Assessment of geothermal resources of the United States-1975: U.S. Geological Survey Circular 726, 155 p.

Richmond, G. M., 1962, Quaternary stratigraphy of the La Sal Mountains, Utah: U.S. Geological Survey Professional Paper 324, 135 p.

Rightmire, C. T., Young, H. W., and Whitehead, R. L., 1976, Geothermal investigations in Idaho, Part 4, Isotopic and geochemical analyses of water from the Bruneau-Grand View and Weiser areas, southwest Idaho: Idaho Department of Water Resources, Water Information Bulletin no. 30, 28 p.

Ross, S. H., 1971, Geothermal potential of Idaho: Moscow, Idaho, Idaho Bureau of Mines and Geology Pamphlet 150, $72 \mathrm{p}$.

Sass, J. H., Lachenbruch, A. H., Munroe, R. J., Greene, G. W., and Moses, T. H., Jr., 1971, Heat flow in the Western United States: Journal of Geophysical Research, v. 76, no. 26, p. 6376-6413.

Stearns, N. D., Stearns, H. T., and Waring, G. A., 1937, Thermal springs in the United States: U.S: Geological Survey WaterSupply Paper 679-B, $200 \mathrm{p}$.

Steward, J. H., and Carlson, U. E., compilers, 1978, Geologic map of Nevada: U.S. Geological Survey, 1 sheet, 1:500,000.

Thomas, C. A., Broom, H. C., and Cummins, J. E., 1963, Magnitude and frequency of floods in the United States, Part 13. Snake River basin: U.S. Geological Survey Water-Supply Paper 1688, $250 \mathrm{p}$.

Toth, J., 1962, A theoretical analysis of ground-water flow in small drainage basins: Journal of Geophysical Research, v. 68, no. 16, p. $4795-4812$.
Truesdell, A. H., and Hulston, J. R., 1980, Isotopic evidence on environments of geothermal systems, in P. Fritz and J. Ch. Fontes, eds., Handbook of environmental isotope geochemistry: New York, Elsevier Scientific Publishing Co., v. 1. 546 p.

White, D. E., 1970, Geochemistry applied to the discovery, evaluation, and exploitation of geothermal energy resources, in United $\mathrm{Na}$ tions Symposium on the Development and Utilization of Geothermal Energy, Pisa, 1970, Proceedings: Geothermics, v. 1, pt. 2, Special Issue 2.

White, D. E., and Williams, D. L., eds., 1975, Assessment of geothermal resources of the United States-1975: U.S. Geological Survey Circular 726, $155 \mathrm{p}$.

Young, H. W., Lewis, R. E., and Backsen, R. L., 1979, Ground-water withdrawals and associated convective heat flux in the Bruneau-Grand View area, southwest Idaho: U.S. Geological Survey Water-Resources Investigations 79-62/Open-File Report, $17 \mathrm{p}$.

Young, H. W., and Mitchell, J. C., 1973, Geothermal investigations in Idaho, Part 1, Geochemistry and geologic setting of selected thermal waters: Idaho Department of Water Resources, Water Information Bulletin no. 30, 43 p.

Young, H. W., and Whitehead, R. L., 1975, Geothermal investigations in Idaho, Part 2, An evaluation of thermal water in the Bruneau-Grand View area, southwest Idaho: Idaho Department of Water Resources, Water Information Bulletin no. 30, 126 p.

Zietz, Isidore, Gilbert, F. P., and Kirby, J. R., Jr., 1978, Aeromagnetic map of Idaho: U.S. Geological Survey Geophysical Investigations Map, GP-920, 1 sheet, 1:1,000,000. 


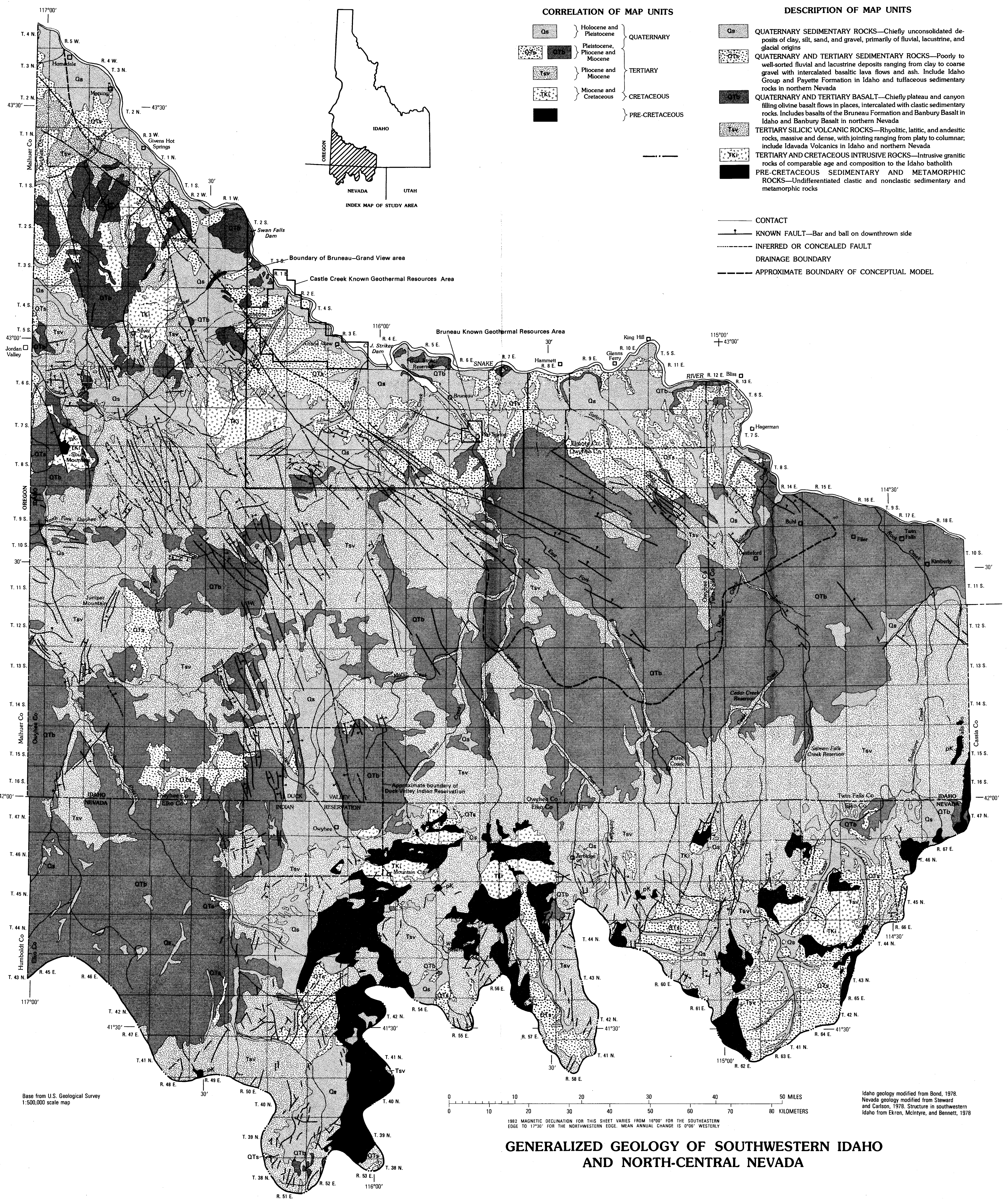



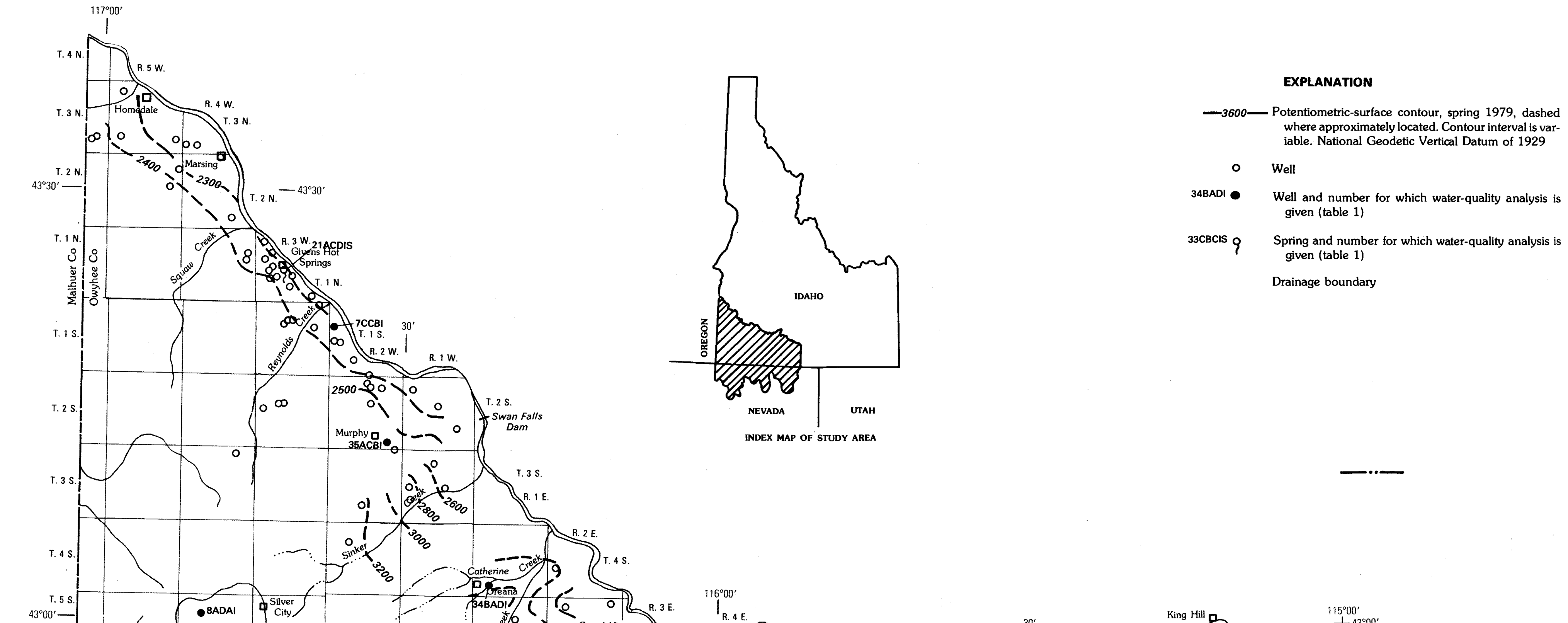

INDEX MAP OF STUDY AREA

$$
\text { (t) }
$$
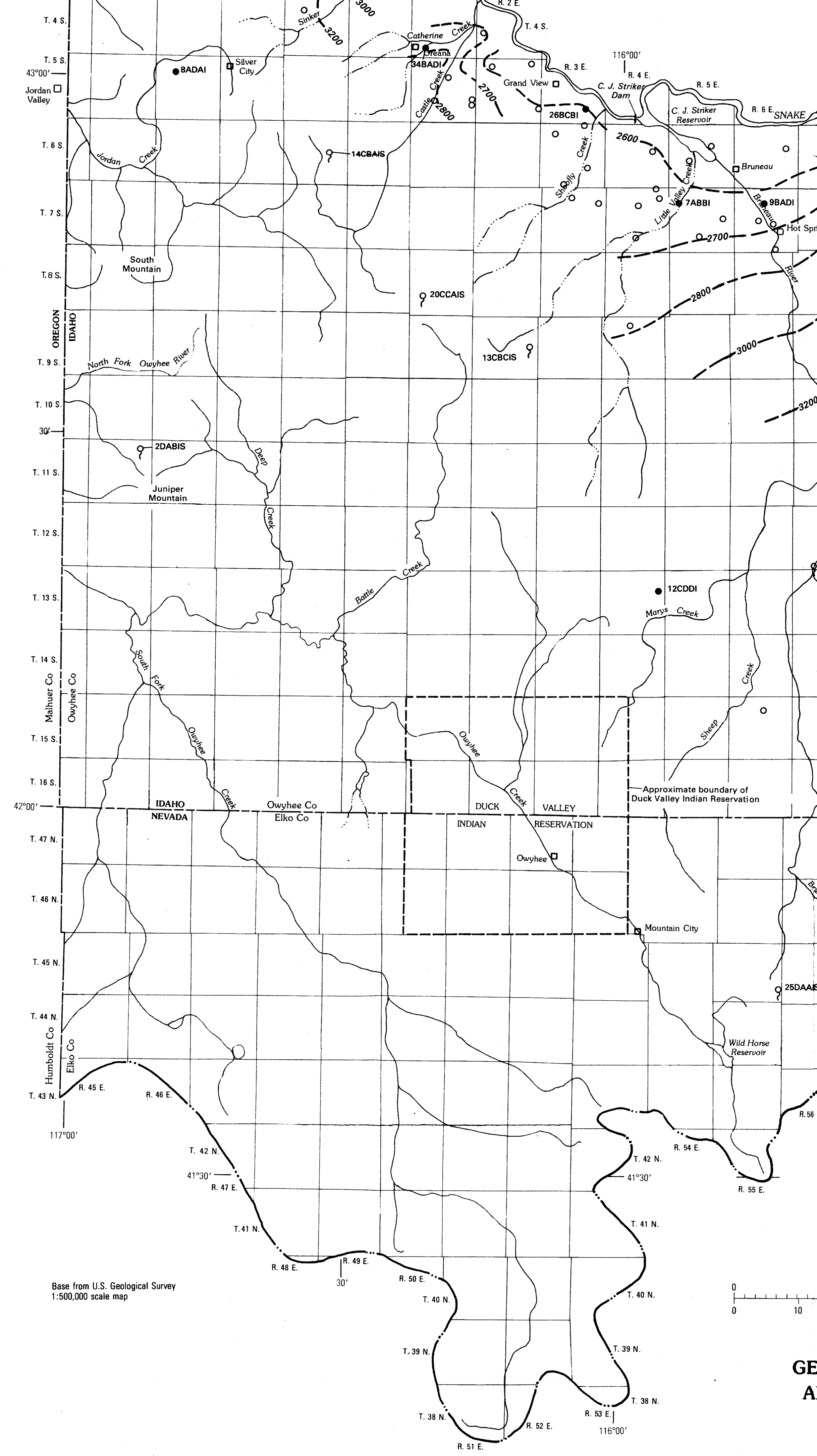

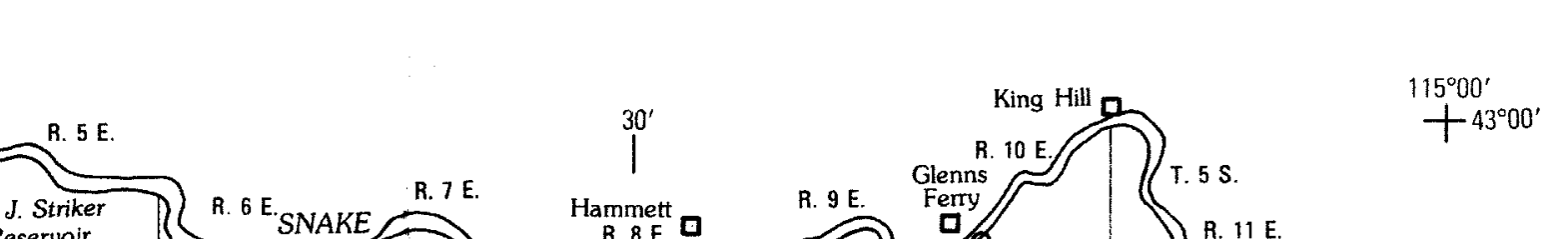

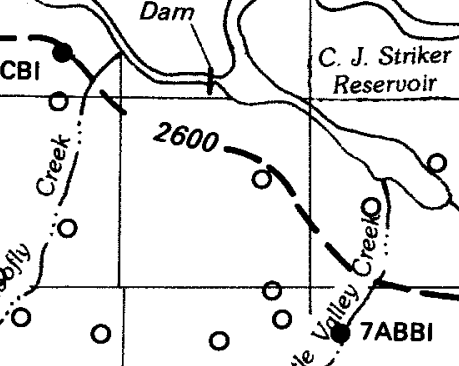

- $-7=-260+7-$

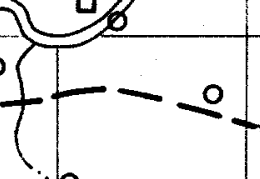

